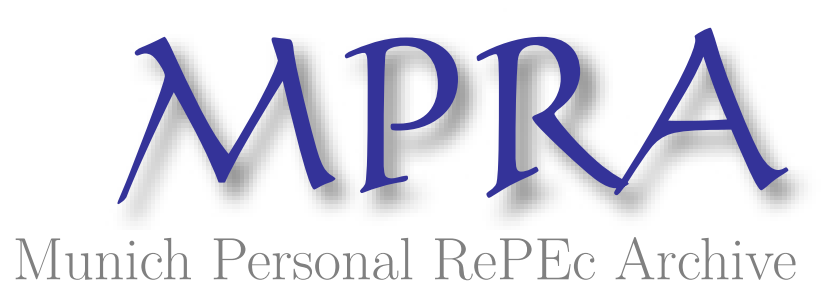

\title{
Micro-, Small and Medium Enterprises in Tajikistan: Drivers of and Barriers to Growth
}

\author{
Tilekeyev, Kanat \\ University of Central Asia
}

1 November 2014

Online at https://mpra.ub.uni-muenchen.de/66719/

MPRA Paper No. 66719, posted 09 Oct 2015 05:39 UTC 


\section{Micro-, Small and Medium Enterprises in Tajikistan: Drivers of and Barriers to Growth}

Kanat Tilekeyev 



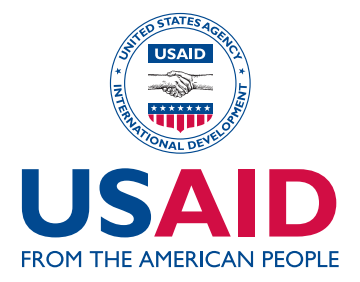

FROM THE AMERICAN PEOPLE

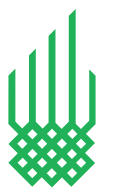

AGA KHAN FOUNDATION

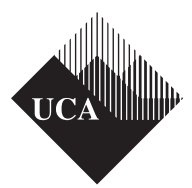

UNIVERSITY

OF CENTRAL ASIA

Graduate School of Development

Institute of Public Policy and Administration

\title{
Micro-, Small and Medium Enterprises in Tajikistan: Drivers of and Barriers to Growth
}

\author{
Kanat Tilekeyev
}

\begin{abstract}
This paper presents the results of a study of the micro-, small and medium enterprise (MSME) sector in Tajikistan, with a focus on its role in the economic growth of the country. Tajikistan has experienced a significant improvement in economic performance during the last decade. This growth is evident in sectors in which MSMEs operate, suggesting the need to better understand the sector and its role in national economic growth. The paper describes the results of a survey of 325 randomly selected, cluster-based enterprises in three key economic sectors in urban and rural areas across Tajikistan: retail trade and services, transportation and agriculture. The dataset provides detailed information on the personal characteristics of entrepreneurs, as well as specific factors influencing the growth of MSMEs, including labour, capital, information and barriers to growth. Analysis of the determinants of making investments, as well as the success of investment decisions of urban entrepreneurs, provides insight into the necessity of developing education opportunities on business and financial planning for MSME owners. Conclusions are presented to help guide policy and programmes that impact the MSME sector and the broader environment in which it functions.
\end{abstract}

\section{Keywords}

Micro-, Small and Medium Enterprises (MSME), Tajikistan, Business Development, Urban Business Development, Rural Business Development, Economic Growth, Business Environment

JEL codes: L26, D22, L21, M21, Q13, L53

This study is made possible by the generous support of the American people through the United States Agency for International Development (USAID). The contents are the responsibility of the author and do not necessarily reflect the views of the USAID or the United States Government. 
The Institute of Public Policy and Administration was established in 2011 to promote systematic and in-depth research on issues related to the socio-economic development of Central Asia, and explore policy alternatives.

The Institute of Public Policy and Administration is part of the Graduate School of Development, University of Central Asia. The University of Central Asia was founded in 2000. The Presidents of Kazakhstan, the Kyrgyz Republic, and Tajikistan, and His Highness the Aga Khan signed the International Treaty and Charter establishing this secular and private university, ratified by the respective parliaments, and registered with the United Nations. The University is building simultaneously three fully-residential campuses in Tekeli (Kazakhstan), Naryn (Kyrgyz Republic) and Khorog (Tajikistan) that will open their doors to undergraduate and graduate students in 2016.

The Institute of Public Policy and Administration's Working Papers is a peer-reviewed series that publishes original contributions on a broad range of topics dealing with social and economic issues, public administration and public policy as they relate to Central Asia.

IPPA Series Editors Bohdan Krawchenko and Roman Mogilevskii

\begin{abstract}
About the author
Kanat Tilekeyev, is Senior Research Fellow of the Institute of Public Policy and Administration of University of Central Asia (UCA). As a Graduate Fellow with the UCA Central Asian Faculty Development Programme, Kanat recently received his PhD in Economics, and his Master's Degree in Transition Studies from the Economics and Business Studies Faculty at the Justus-Liebig-University-Giessen in Germany.
\end{abstract}

The findings, interpretations and conclusions expressed in this paper are entirely those of the author and do not necessary represent the view of the University of Central Asia.

Text and data in this publication may be reproduced as long as the source is cited. 


\section{Contents}

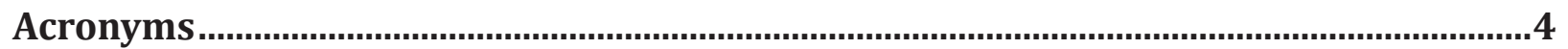

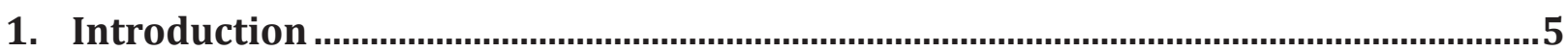

2. Mapping the Contribution of MSMEs to the Economy of Tajikistan...........................5

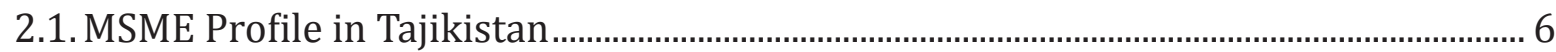

2.2. The Role of MSMEs in the Growth of the Economy ............................................................ 8

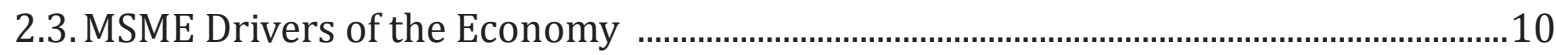

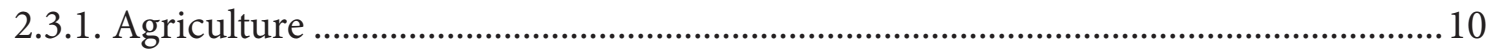

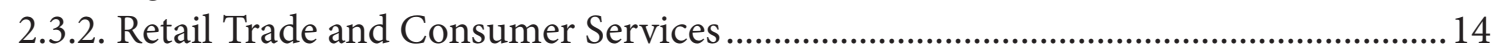

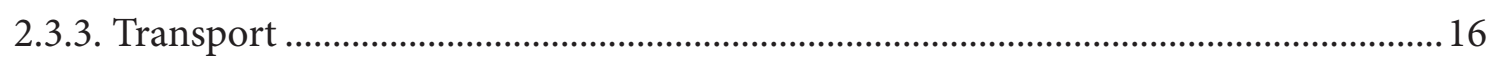

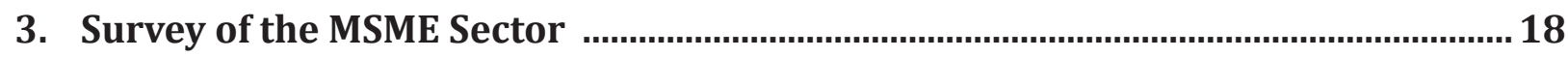

3.1. Sampling Methodology.......................................................................................................

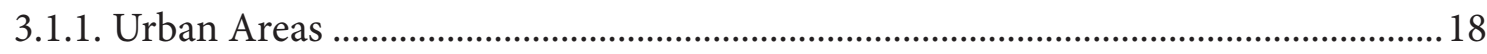

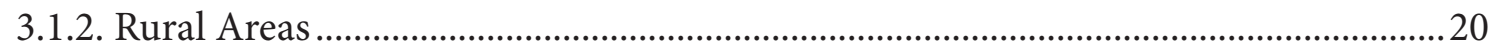

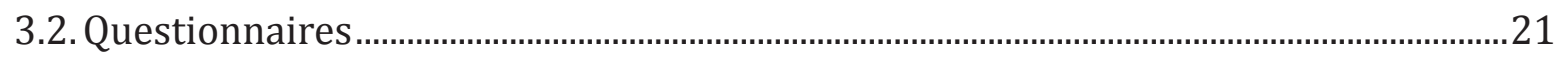

4. Entrepreneur Profile and Factors Impacting MSME Growth.................................. 22

4.1. The Profile of Entrepreneurs in Tajikistan ..........................................................................22

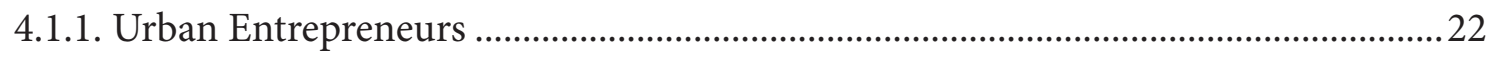

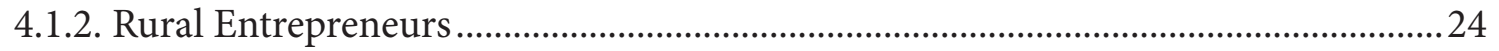

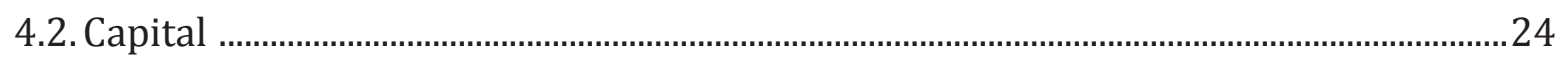

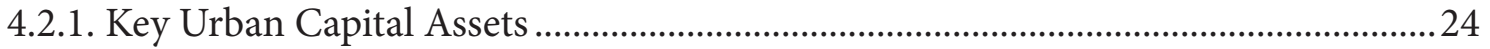

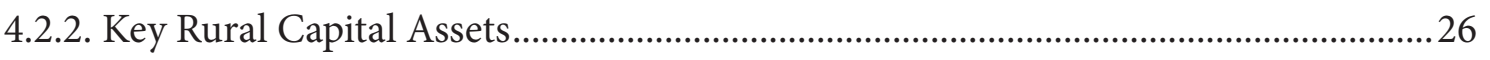

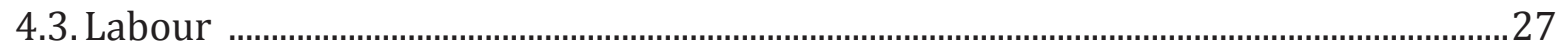

4.3.1. Labour Trends in Urban MSMEs ……….................................................................2 27

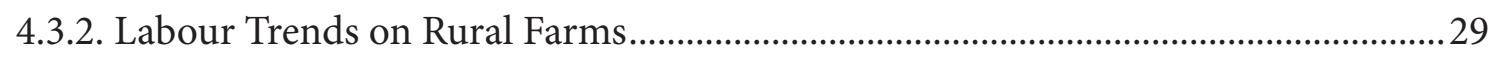

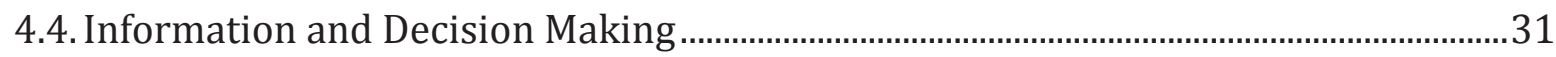

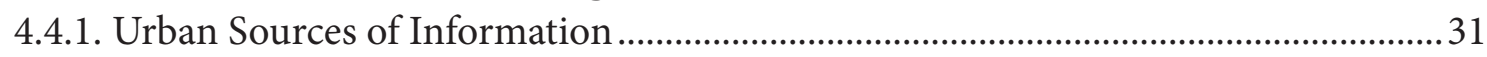

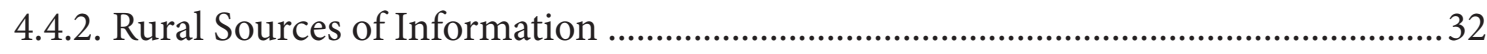

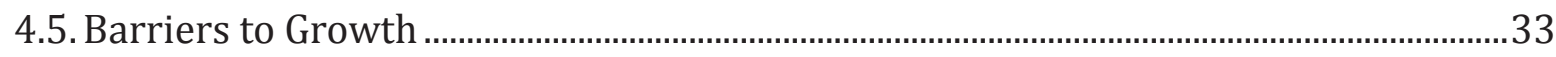

5. Factors Shaping Investments in the Development of MSMEs ...................................34

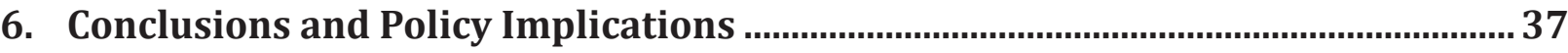

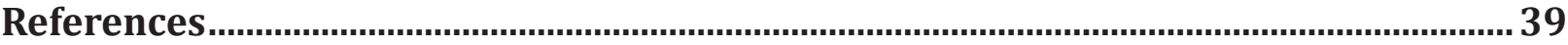

\section{Tables}

Table 1. Main Sources of Retail Trade in Tajikistan, 2006 -2012 _.............................................14

Table 2. Final Sample of Urban Respondents.............................................................................. 19

Table 3. Final Sample of Rural Households ............................................................................ 20

Table 4. Questionnaire Sections.................................................................................................21

Table 5. Multinomial Logit Model Estimates of Investment Determinants of Urban Entrepreneurs in Tajikistan . 


\section{Figures}

Figure 1. Distribution of Types of Individual Enterprises by Region in Tajikistan, 2011 (\%) .... 7

Figure 2. Small Enterprise Indicator Dynamics, 2005-2011 ...................................................... 7

Figure 3. Growth of GDP in Tajikistan in Nominal and Real Terms, 2000-2012 .................... 8

Figure 4. Dynamics of GDP Structure in Tajikistan, 2002-2009 (\%) .......................................... 9

Figure 5. Dynamics of Agricultural Production by Sector in Constant 2012 Prices,

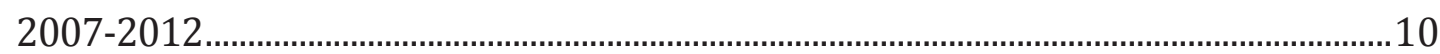

Figure 6. Share of Agricultural Production by Farm Type, 2007 and 2012 (\%) ..................11

Figure 7. Average Land Plot per Household by Region, 2007, 2009 and 2012 ....................12

Figure 8. Onion Exports from Tajikistan to Russia and Kazakhstan, 2008-2012 .................12

Figure 9. Onion Imports from Tajikistan by Russia and Kazakhstan, 2008-2012 2................13

Figure 10. Dried Fruit Exports from Tajikistan to Russia, Kazakhstan and Ukraine, 2008-2012

Figure 11. Dried Fruit Imports from Tajikistan by Russia, Kazakhstan and Ukraine, 2008-2012 (thousand tons and million USD) ...............................................................13

Figure 12. Dynamics of Trade in Tajikistan in Constant 2012 Prices, 2006-2012..................15

Figure 13. Regional Distribution of Retail Trade Turnover by Type of Market Channel, $2012(\%)$

Figure 14. Dynamics of Paid Services in Tajikistan in Constant 2012 Prices, 2006-2012 ......16

Figure 15. Dynamics of Freight Transportation by Types of Transport, 2007-2011 ............17

Figure 16. Dynamics of Passenger Transportation by Types of Transport, 2007-2011 .......17

Figure 17. Distribution of Urban Clustered Sample in Dushanbe...............................................19

Figure 18. Distribution of Rural Clustered Sample in Kulkand Village......................................21

Figure 19. Age and Duration in Current Business of Urban Entrepreneurs ............................22

Figure 20. Form of Registration of Urban MSMEs ......................................................................23

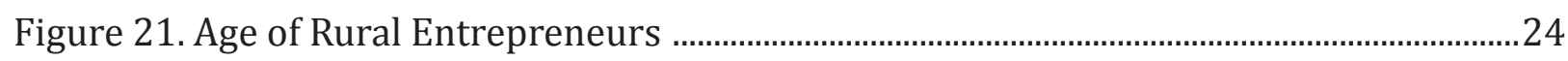

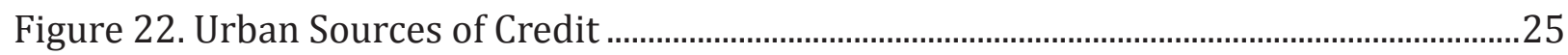

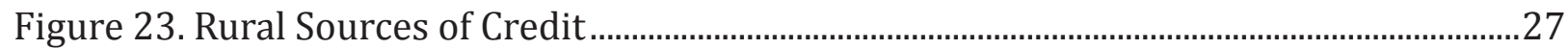

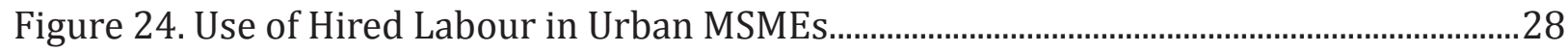

Figure 25. The Role of Family Members in Urban MSMEs ...........................................................29

Figure 26. The Role of Family Members in Rural MSMEs................................................................30

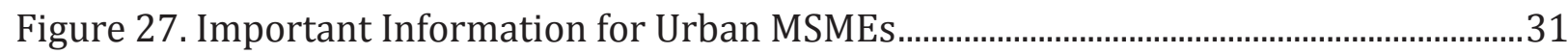

Figure 28. Important Information for Rural MSMEs …............................................................ 32

Figure 29. The Institutional Environment of Urban and Rural MSMEs.....................................34

Figure 30. Main Investments of Urban MSMEs ...............................................................................35 


\section{Introduction}

This paper presents the results of a study of the micro-, small and medium enterprise (MSME) sector in Tajikistan, with a focus on its role in the economic growth of the country. Tajikistan has experienced a significant improvement in economic performance during the last decade, with gross national income (GNI) per capita increasing in real terms by 45 percent between 2000 and 2012. ${ }^{1}$ The role of the MSME sector, and particularly micro businesses, in the current stage of Tajikistan's development is important and inadequately investigated. MSMEs could prove critical to national economic growth due to their potential to absorb unemployment, their ability to foster mobility in a complicated business environment, and their potential to increase sustainability and competitiveness of the economy in regional and global contexts.

Within the national context, recent policy changes by the Government of Tajikistan could positively affect the MSME sector, including:

- Agricultural reform;

- Tariff reorganisation, due to the accession of Tajikistan to the World Trade Organisation; and

- Tax reform.

This study provides an assessment of the MSME sector and its impact on the economic development of Tajikistan, as well as an analysis of the main drivers of, and barriers to, the sector's development. Chapter 2 analyses the role of key drivers of economic growth within the sector, including an overview of the characteristics of MSMEs, key growth sectors and a detailed description of sub-sectoral development. Chapters 3 and 4 describe a field survey of MSMEs in selected sub-sectors and clustered areas across the country and provide an analysis of survey responses on growth factors. Methodology and sample selection are described in Chapter 3 , while Chapter 4 presents the profile of surveyed micro-entrepreneurs and growth factors of micro-businesses. Chapter 5 presents the results of the empirical analysis of responses on investments in business in relation to behavioural characteristics of entrepreneurs. These findings could help guide efforts to alleviate constraints to business growth. Chapter 6 presents conclusions, with a focus on policy gaps.

\section{Mapping the Contribution of MSMEs to the Economy of Tajikistan}

This chapter describes the main trends of economic development in Tajikistan as they relate to the MSME sector. Defining features of MSMEs are presented in section 2.1. Section 2.2. describes the connection between economic growth and the development of driver sectors. Finally, section 2.3. highlights the links between selected sectors and MSME development.

$1 \quad$ According to the World Bank, GNI per capita increased from \$313 in 2004 to \$454 in 2012. http:// data.worldbank.org/indicator/NY.GNP.PCAP.CD/countries/TJ-7E-XM?display=graph (date accessed: December 2013) 


\subsection{MSME Profile in Tajikistan}

All business activity in Tajikistan requires legal registration. According to Tajik law, ${ }^{2}$ small entrepreneurs are defined as:

- Private entrepreneurs or companies with limited (less than 25 percent) state ownership;

- Having limited turnover (not more than four times their threshold under the Tax Code );

- Employing less than 30 persons in non-agricultural sectors and up to 50 persons in agricultural sectors; and

- Not involved in the production of excise tax products, aluminum production, mining, banking and insurance, investment and the stock exchange.

In 2005, the total number of registered businesses in Tajikistan was around 45,000, which increased to 63,000 by 2008 . In 2009 , the number fell to a third of that, due to declining business prospects caused by the food and financial crises. In 2010, the sector began to grow again, at a slower pace.

Registered businesses primarily include private and collective enterprises, with a small share of state enterprises. In 2012, 206,300 business units were registered in Tajikistan. Of these, the majority $(177,000)$ were individual entrepreneurs, 29,000 were legal business entities (companies) and 321 were foreign companies or their branches. ${ }^{3}$

The regional distribution of registered business entities varies according to location. In 2012, the majority of businesses were registered in the capital city, Dushanbe (24 percent) and in the surrounding Region of Republican Subordination (24 percent). Almost a third of registered businesses were registered in Khatlon Province (30 percent) and a quarter in Sughd Province (24 percent). Gorno-Badakhshan Autonomous Province had the least share of registered businesses ( 4 percent) due to its low population share and economic potential.

Individual businesses in Tajikistan operate within a less formal institutional framework, without the many formal obligations of state bodies. Registration and reporting systems for these entities are relatively simple. Official data found 200,000 such businesses in 2012, run by individual entrepreneurs under the following categories: certificate, patent and private or dekhan farm. ${ }^{4}$

Up to 100,700 self-employed micro-businesses work by the patent system, 40,700 small businesses prefer certificates ${ }^{5}$ and 58,300 operate in the agricultural sector ${ }^{6}$ as dekhan farms. ${ }^{7}$ The largest number of dekhan farms are in Khatlon Province. Sughd Province exceeds other areas in the number of patent individual enterprises, and Dushanbe leads in

$2 \quad$ Article 7 of the Law of Republic of Tajikistan, "On state protection and support of entrepreneurship in the Republic of Tajikistan” editions No. 98 (25 July. 2005) and No. 259 (12 May 2007).

3 Statistical Agency of the Republic of Tajikistan (SART), "Statistical Yearbook of the Republic of Tajikistan 2012" (Dushanbe: SART, 2012). In Russian/Tajik.

4 Ibid.

5 Ibid.

6 SART, "Agriculture of the Republic of Tajikistan 2013" (Dushanbe: SART, 2013). In Russian/Tajik.

7 There are statistical inconsistencies in data on the agricultural sector in the different reports. This paper includes the most recent data. 
certificates (see Figure 1). Women are not represented equally in small businesses. Only about 14 percent of both certificate enterprises and dekhan farms, and 16 percent of patents, were registered by women. ${ }^{8}$

Figure 1. Distribution of Types of Individual Enterprises by Region in Tajikistan, 2011 (\%)

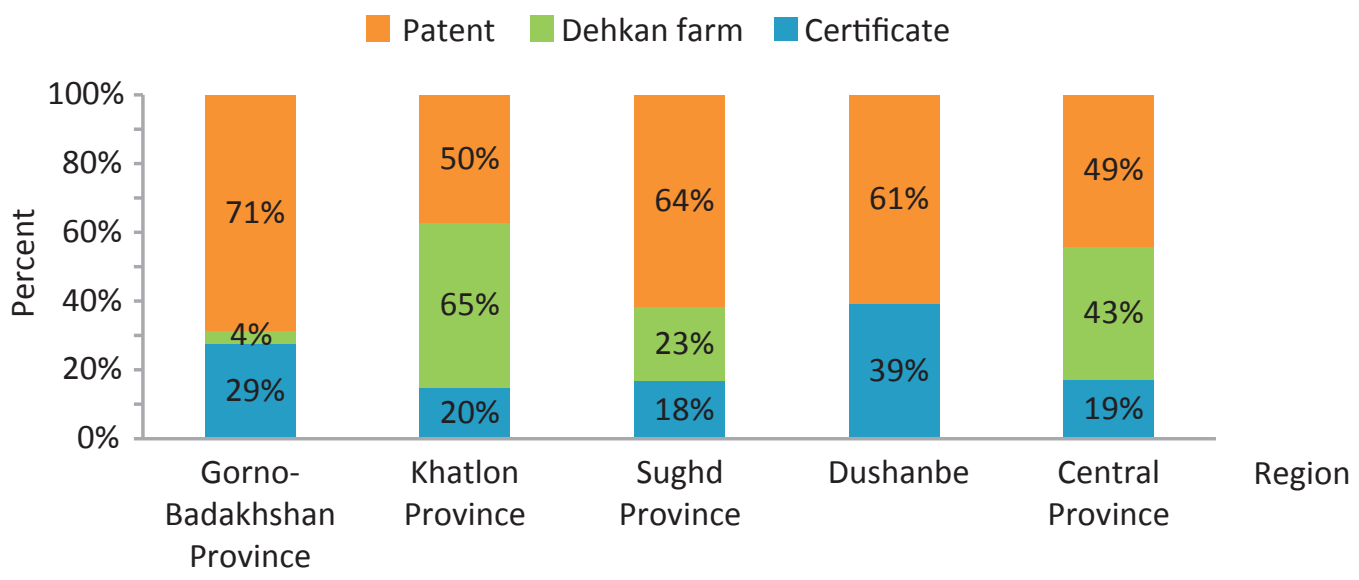

Source: Statistical Agency of the Republic of Tajikistan (SART), Statistical Yearbook of the Republic of Tajikistan 2012 (SART, 2012)

The number of MSMEs functioning as registered companies doubled from 1,700 in 2005 to 3,400 in 2011. These companies employed an average of 17,000 to 20,000 workers. Employment in this sector increased to 20,900 workers in 2009 and then slightly declined. Turnover of MSMEs per business increased to $\$ 200,000$ in 2008, but dropped dramatically in 2009 to $\$ 125,000$. Since 2010, turnover has gradually increased (see Figure 2).

Figure 2. Small Enterprise Indicator Dynamics, 2005-2011

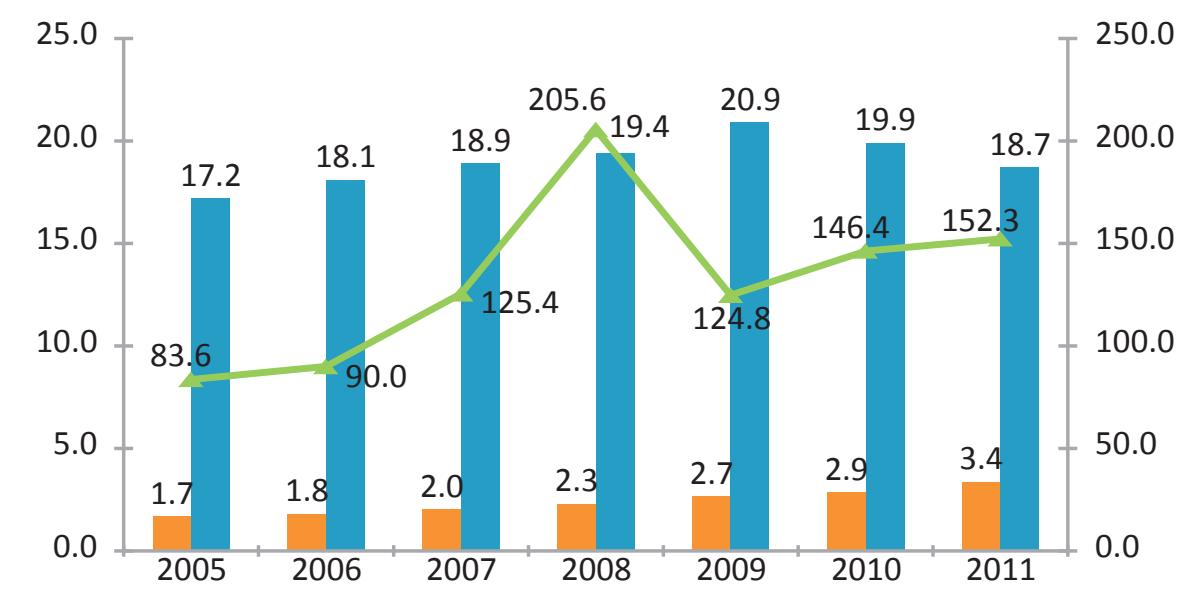

SME, thousands of units SME Labour, thous. pers. $\quad$ Turnover per Unit, thous. USD

Source: SART, Statistical Yearbook of the Republic of Tajikistan (SART, 2012).

$8 \quad$ SART, "Statistical Yearbook of the Republic of Tajikistan" Technical Report (Dushanbe: SART, 2012). In Russian/Tajik. 
The Tajik economy, including the MSME sector, was affected by the financial and food crises of 2008 and 2009. Analysis of data from official sources indicates that the number of enterprises and the economic performance of MSMEs are stagnating, except in the rural sector. The number of dekhan farms is increasing as a result of ongoing agricultural reform.

A significant proportion of Tajik small businesses are classified as patents and certificates and estimating their economic performance using official statistics can be complicated due to absence of detailed reporting system.

\subsection{The Role of MSMEs in the Growth of the Economy}

The economy of Tajikistan has experienced significant growth since 2000. The growth rate of the Gross Domestic Product (GDP) in nominal terms averaged 8.3 percent from 2000 to $2012,{ }^{9}$ with a deviation of only 3.6 percent growth rate in 2009 , due to the food and financial crises. This rapid increase in the national economy led to a 3.5 increase in nominal GDP per capita from 2002 to $2009,{ }^{10}$ while in real terms, GDP increased by 2.5 times in the observed period (see Figure 3).

Figure 3. Growth of GDP in Tajikistan in Nominal and Real Terms, 2000-2012

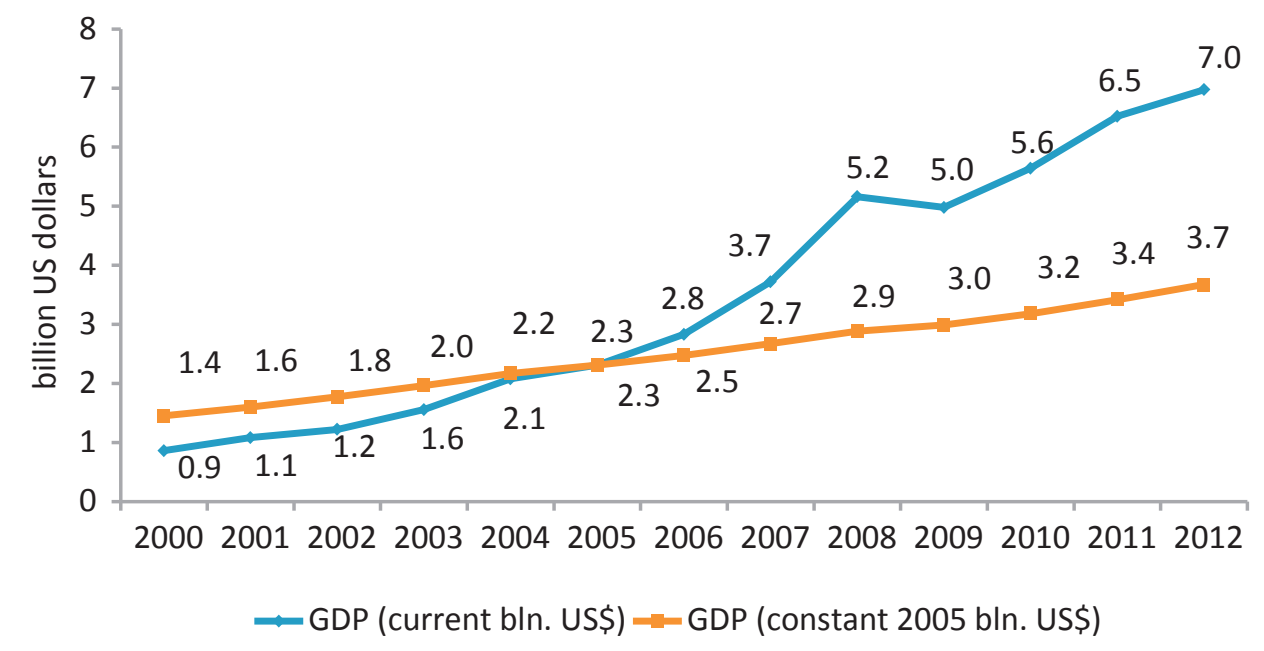

Source: The World Bank, http://data.worldbank.org/country/tajikistan (date accessed: December 2013)

This impressive economic growth can be explained by the rapid expansion of key economic sectors: the domestic trade sector (including retail trade, canteen services and storage facilities), construction, transportation and communications (Figure 4). The share of the trade sector in GDP almost doubled from 11 percent in 2002 to 21 percent in 2009. The physical volume of value added in this sector grew by 78.8 percent from 2005 to 2009. In

\footnotetext{
9 The World Bank, http://data.worldbank.org/country/tajikistan, (date accessed: December 2013).

10 SART, National Accounts of the Republic of Tajikistan (Dushanbe: SART, 2010). In Russian/Tajik.
} 
comparison, agriculture showed 35.6 percent growth of the same indicator, and industry declined by 13.8 percent. $^{11}$

The construction sector showed similar rapid growth. Its share in the economy increased from two percent in 2002 to ten percent in 2009. Physical volume of the value added of the construction sector increased by 41 percent from 2005 to 2009. In 2009, the sector showed a decrease of 15 percent, compared to $2008 .^{12}$

The transportation and communications sectors increased their share in GDP from 6 to 11 percent. The physical volume of value added of transportation grew by 80.7 percent from 2005 to 2009. In the same period, communications demonstrated tremendous growth, increasing 6.7 times and adding value at an average annual rate of 48 percent. ${ }^{13}$

Trade, construction, transportation and communications increased their total share in GDP from 19 percent in 2002 to 42 percent in 2009. From 2005 to 2009, their total share in constant prices in national currency quadrupled, compared to other sectors, which increased by 2.3 times. GDP increased by 2.8 times in the same period. ${ }^{14}$

Figure 4. Dynamics of GDP Structure in Tajikistan, 2002-2009 (\%)

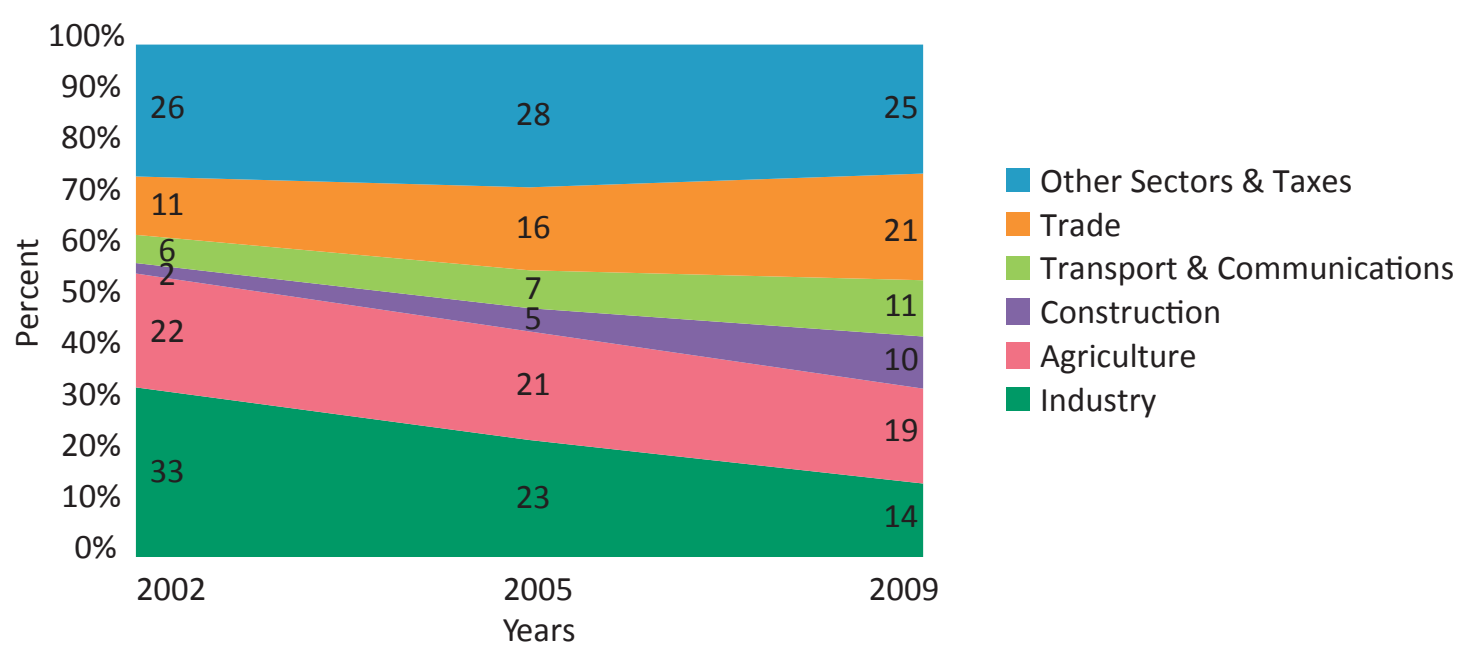

Source: SART, National Accounts of the Republic of Tajikistan (SART, 2010).

The increasing rate of economic activity within these sectors was the main driver of economic growth in Tajikistan from 2002 to 2009. However, with regard to MSMEs and their role in economic growth, the domestic trade, transportation and agriculture sectors are more relevant than the construction and communications sectors. The construction boom is most likely based on state investments, and both construction and communications require large investments unavailable to the majority of MSMEs.

\footnotetext{
Ibid, 38, 43.

Ibid.

Ibid.
}

14 Ibid, 41 


\subsection{MSME Drivers of the Economy}

\subsubsection{Agriculture}

Agriculture is one of the most important economic sectors in Tajikistan, due to the high concentration of the population in rural areas. The sector is one of the most complicated sectors to analyse, due to protracted land reform, institutional and market distortion caused by state control of the main export cotton, ${ }^{15}$ and weak transformational processes complicated by inadequate financial and technological resources. ${ }^{16}$ The current status of agricultural reform is complicated by the unfinished process of land reorganisation. Nevertheless, distribution of land from collective to dekhan farms increased during the last five years.

The sector's share in GDP decreased slightly from 22 percent in 2002 to 19 percent in 2009, but in real terms, its growth was significant. Agriculture increased in volume of the value added in constant prices by 3.8 times from 2005 to 2009. This occurred despite low levels of mechanisation, problems with technological inputs and irrigation, ongoing reform of the sector and strong outflows of labour from rural areas to jobs abroad. ${ }^{17}$ During the last five years, production within the sector increased by 53 percent, mainly due to growth in crop production (see Figure 5).

Figure 5. Dynamics of Agricultural Production by Sector in Constant 2012 Prices, 2007-2012 ${ }^{18}$

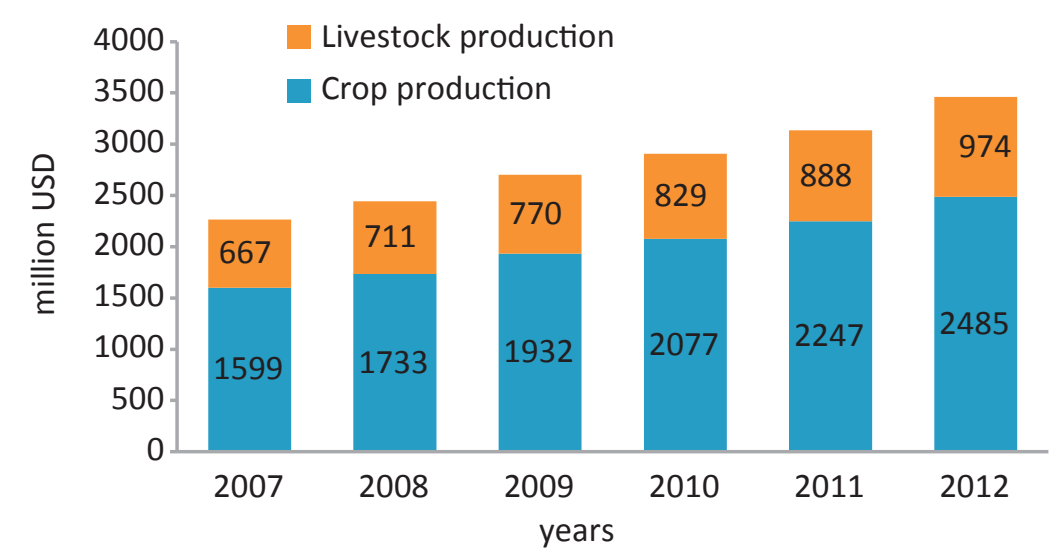

Source: SART, Agricultural Production in the Republic of Tajikistan (SART, 2013)

A significant portion of agricultural production is not controlled by the state, which makes the sector amenable to MSMEs. Micro-scale family production on household land plots (kitchen gardens) and livestock production are responsible for most agricultural produc-

15 Cotton production is not an MSME activity and is not considered in this paper.

16 The World Bank, "Priorities for Sustainable Growth: A Strategy for Agriculture Sector Development in Tajikistan." Technical Report No 68418 Vol. 1, (2012), 18-20. http://documents.worldbank.org/ curated/en/2012/01/16247698/tajikistan-priorities-sustainable-growth-strategy-agriculture-sectordevelopment-vol-1-4-main-report (date accessed: December 2013).

17 The World Bank, "Republic of Tajikistan Country Economic Memorandum: Tajikistan's Quest for Growth: Stimulating Private Investment”, Technical Report No. 54677-Tj (2011), http://www-wds.worldbank.org/ external/default/ (date accessed: December 2013).

18 Volumes of trade were recalculated by average exchange rates for each year separately. This is also true of further production or turnover data provided in US dollars in the chapter. 
tion in the country, despite gradual decreases due to the growth of dekhan farms during the last five years (see Figure 6).

Between 2007 and 2012, the share of rural households involved in the production of livestock products remained high at between 93 and 94 percent. Rural households also produced a significant share of crop production; between 56 and 58 percent in the same period. ${ }^{19}$ The share of rural households declined in the observed period in favour of dekhan farms due to land reform. Land redistributed to dekhan farms increased their share in cultivated lands to 59 percent, while the share of household plots was stable at 22 to 23 percent in 2007-2012. The share of collective farms gradually decreased, from 24 to 17 percent in the same period. ${ }^{20}$

Figure 6. Share of Agricultural Production by Farm Type, 2007 and 2012 (\%)

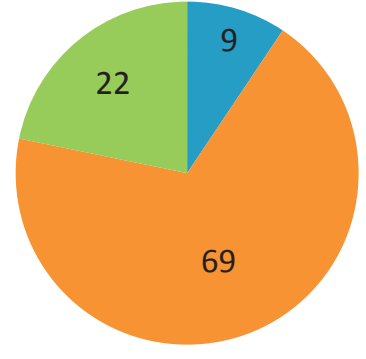

2007

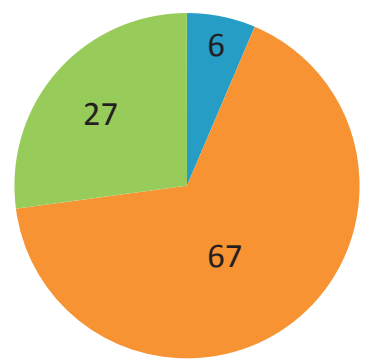

2012 collective farms

household production

dehkhan farms

Source: SART, Agricultural Production in the Republic of Tajikistan (SART, 2013)

In 2012, rural households produced 39 percent of all grain, 54 percent of potatoes, 61 percent of vegetables, 65 percent of fruit and 62 percent of grapes in Tajikistan. ${ }^{21}$ The share of rural households in meat and milk production exceeded 90 percent, and for wool and egg production was at 82 and 36 percent respectively. ${ }^{22}$ Household production is usually labour-intensive. Without access to technological inputs, such as improved seeds, fertilisers and machinery, intensive use of labour has proven central to increasing rural productivity in Tajikistan.

Access to land is not consistent across the country due its natural topography and population distribution. Larger plots for kitchen gardens are mostly available in Khatlon Province and the Region of Republican Subordination. The sizes of plots in Sughd and Gorno-Badakhshan Autonomous provinces are smaller due to high population density in Sughd and lack of available land in Gorno-Badakhshan (see Figure 7). Since 2007, in Khatlon Province and the Region of Republican Subordination, the size of plots has decreased slightly. In Sughd Province, it has stabilised and in Gorno-Badakhshan Autonomous Province, it has slowly increased.

Notably, 800,000 rural households in Tajikistan are the main source of agricultural production in the country. Some argue that this small-scale activity is simply oriented towards rural subsistence and cannot significantly impact national economic development. However, further examination of agricultural exports other than cotton, such as onions and dried fruit, provides contrary evidence on the impact of rural households on export and business development in Tajikistan.

SART, Agriculture of the Republic of Tajikistan (Dushanbe: SART, 2013). In Russian/Tajik.

Ibid, 27.

Ibid, 36-39.

Ibid, 52-53. 
Figure 7. Average Land Plot per Household by Region, 2007, 2009 and 2012 (hectares per household)

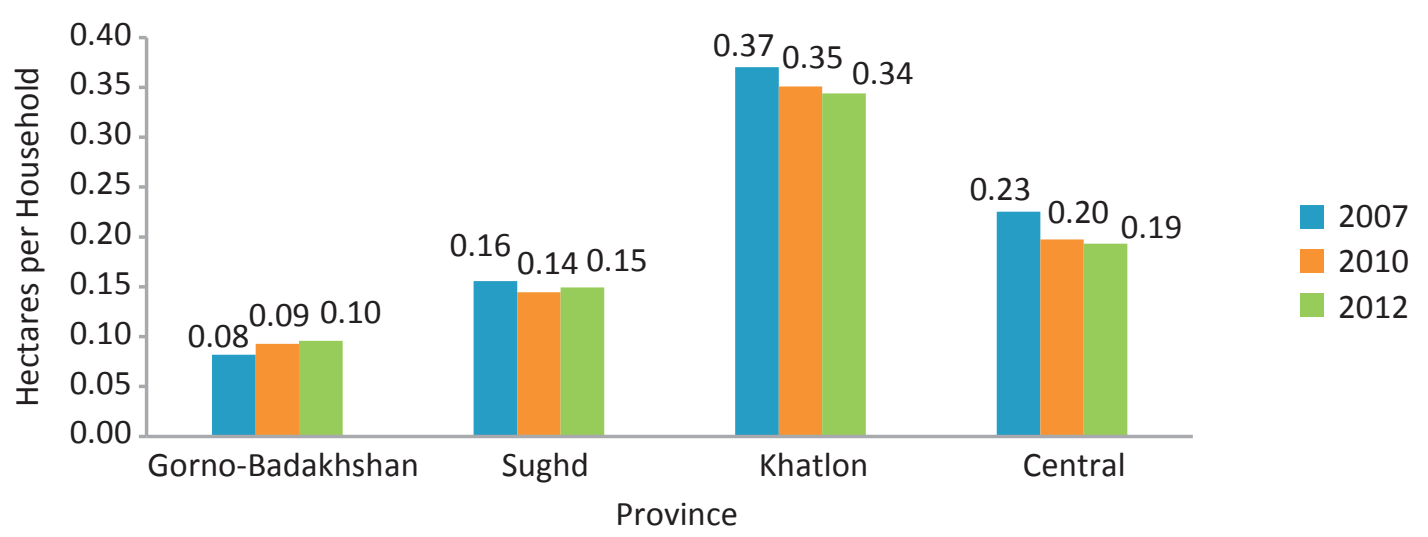

Source: SART, Agricultural Production in the Republic of Tajikistan (SART, 2013) and SART, Census of Population and Housing of the Republic of Tajikistan, 2010 Volume 5 (SART, 2010)

From 2008 to 2012, 96 percent of all Tajik onion exports were to Russia and Kazakhstan, with physical volumes ranging from 55,000 to 130,000 tons. Since 2010, a decrease in exports to Russia saw simultaneous growth in exports to Kazakhstan; most likely due to Kazakhstan joining the Customs Union ${ }^{23}$ (see Figure 8). According to official customs data, the overall share of onion exports was not significant, ranging from just 0.5 to one percent of total exports. In 2010, onion exports peaked at \$15 million, but typically, between 2008 and 2012, they generated between $\$ 7$ and 8 million dollars annually (see Figure 8).

A different picture emerges if mirror data is used. Using the COMTRADE data set of cost and weight data, disaggregated by the four-digit Harmonized System, onion imports from Tajikistan by Russia and Kazakhstan from 2008 to 2012 were analysed. No significant difference was found between exports measured in the weight volumes. However, a significant difference was observed in cost values (see Figure 9). The maximum difference in values is observed in 2010, with record sales of onions totaling $\$ 42.5$ million; more than double the export cost value.

Figure 8. Onion Exports from Tajikistan to Russia and Kazakhstan, 2008-2012 (thousand tons and million USD)
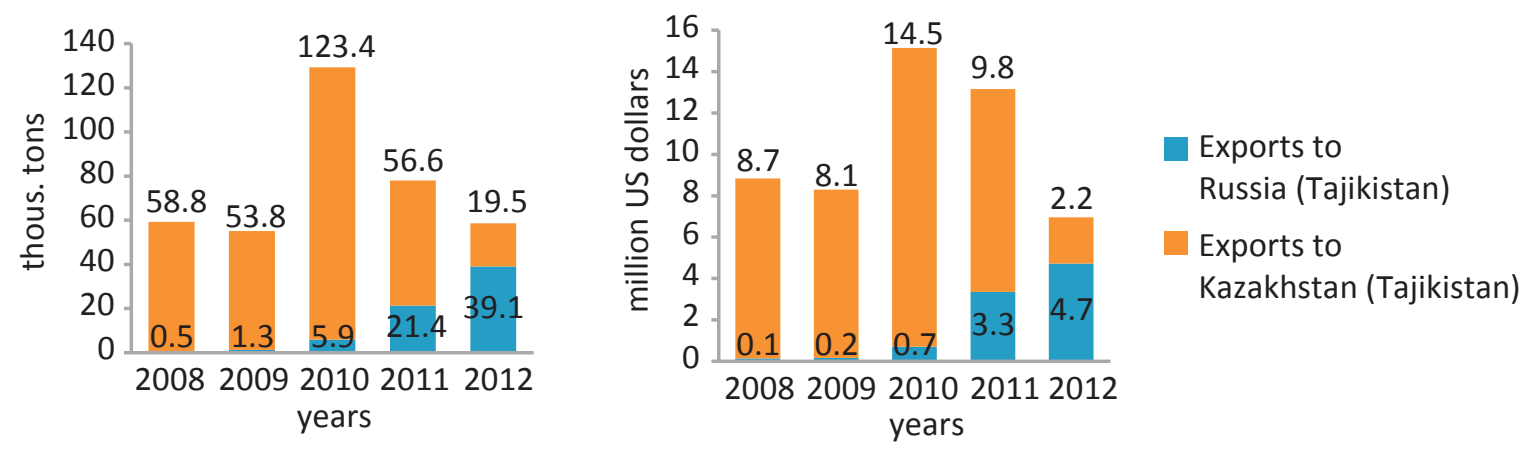

Source: State Customs Service under the Government of the Republic of

Tajikistan, http://www.customs.tj (date accessed: January 2014)

$23 \quad$ Roman Mogilevskii and Kamiljon Akramov, "Trade in Agricultural and Food Products in Central Asia”, Institute of Public Policy and Administration Working Paper No 27 (Bishkek: University of Central Asia, 2014). 
Figure 9. Onion Imports from Tajikistan by Russia and Kazakhstan, 2008-2012 (thousand tons and million USD)
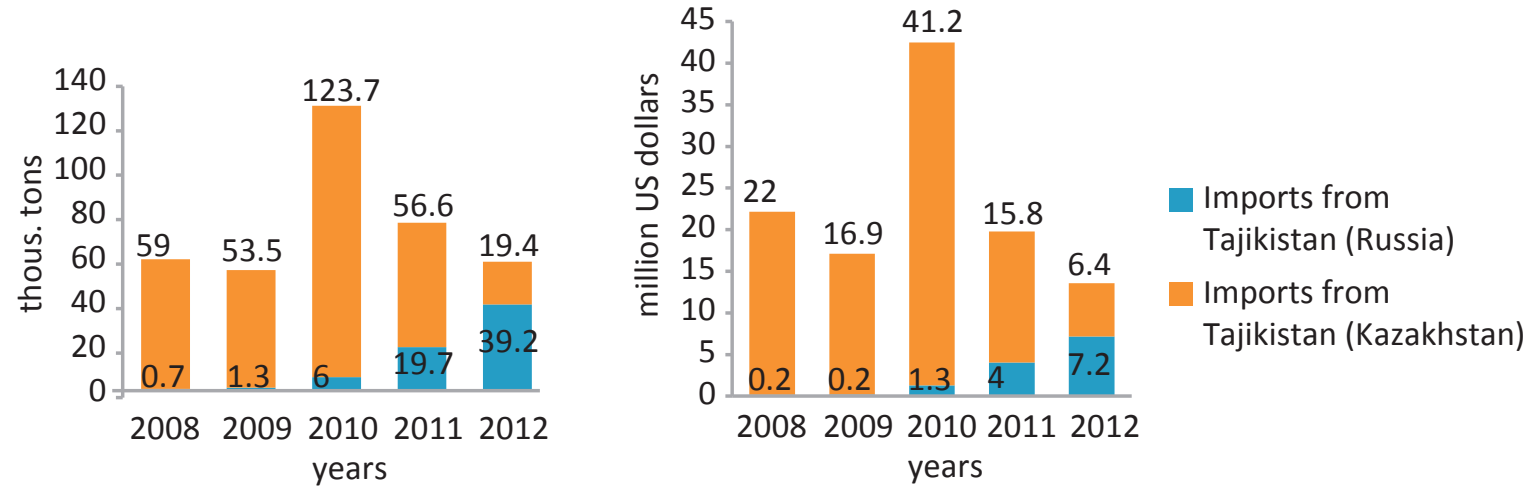

Source: COMTRADE, http://comtrade.un.org (date accessed: January 2014)

A second example of the impact of small scale farming on exports can be seen in the case of dried fruit, a national specialty traditionally exported by Tajikistan to Commonwealth of Independent States (CIS) markets of Russia, Kazakhstan and Ukraine. Exports of dried fruit to these three counties make up, on average, 96 percent of total exports in weight and 93 percent in cost volumes. In the last five years, Tajikistan typically exported between 65 and 75,000 tons of dried fruit annually. As in the case of onions, and for the same reasons, since 2010, dried fruit exports have seen a decrease in exports to Russia and a corresponding increase in exports to Kazakhstan. The customs value of the product has not changed significantly, varying from $\$ 22$ to 24 million dollars (see Figure 10).

Figure 10. Dried Fruit Exports from Tajikistan to Russia, Kazakhstan and Ukraine, 2008-2012 (thousand tons and million USD)
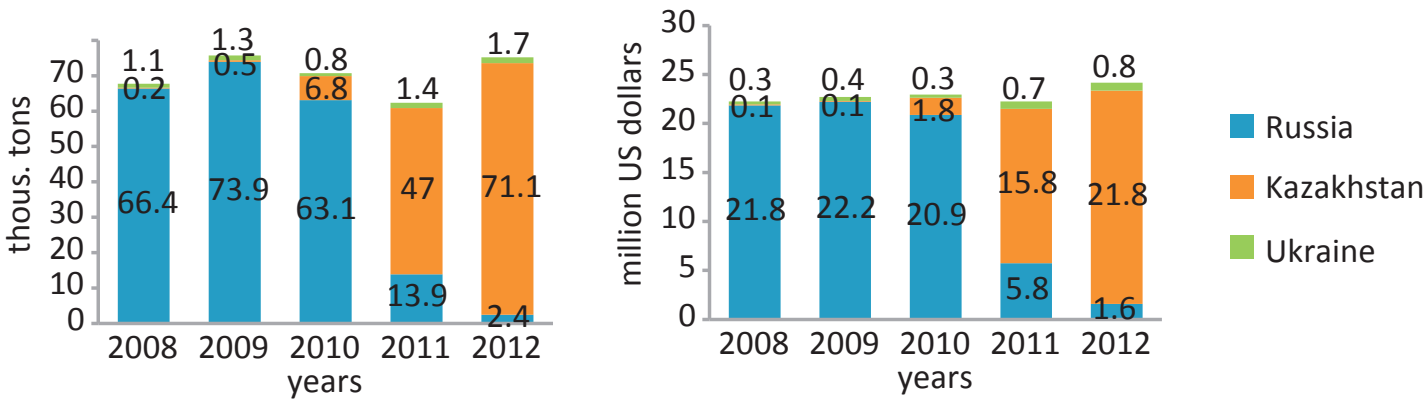

Source: State Customs Service under the Government of the Republic of

Tajikistan, http://www.customs.tj (date accessed: January 2014)

Figure 11. Dried Fruit Imports from Tajikistan by Russia, Kazakhstan and Ukraine, 2008-2012 (thousand tons and million USD)
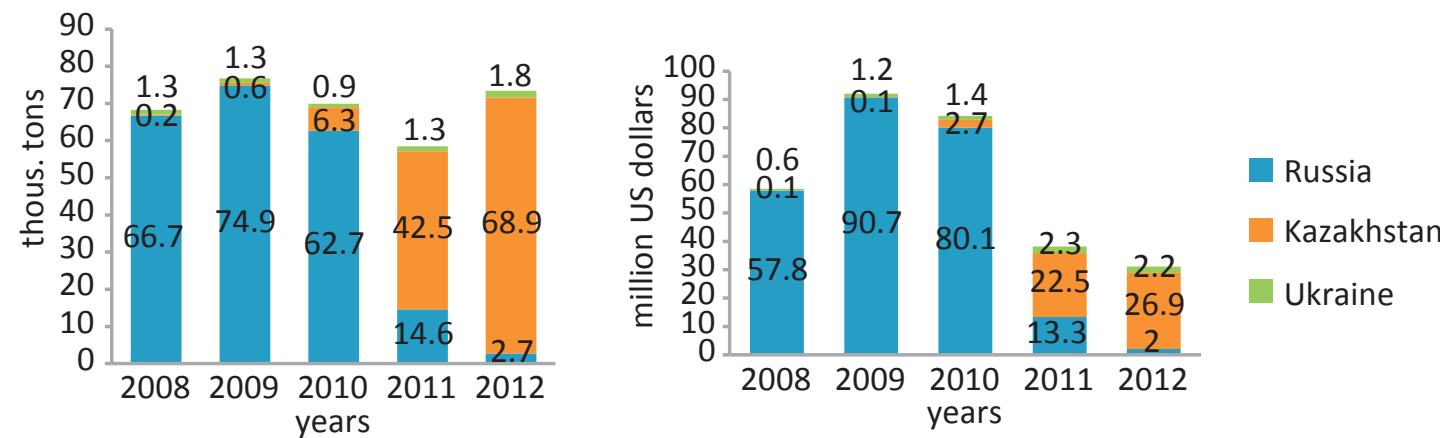

Source: COMTRADE, http://comtrade.un.org (date accessed: January 2014) 
The mirror data from COMTRADE once again highlights a discrepancy between the data sets. The volume of dried fruit imports from Tajikistan to Russia, Kazakhstan and Ukraine peaked in 2009 at $\$ 92$ million and declined to $\$ 31$ million in 2012. The difference in dried fruit exports in cost volumes reach 400 percent in 2009, with a minimum of 30 percent registered again in 2012. The difference in the weight of the supply volume remained insignificant.

It should be noted that Russia and Ukraine imported Tajik dried fruit at a higher price $(\$ 1,000$ to 1,200 per ton), while Kazakhstan imported dried fruit at a significantly lower price ( $\$ 400$ per ton). This is due to the rapid decrease of export volumes in monetary value in the last two years, while supplies in natural volumes remained the same (see Figure 11).

The examples of onion and dried fruit exports indicate that:

- Export volumes of agricultural products may be underestimated. Even accounting for the transportation costs of onions (an insignificant cost for dried fruit which is exported in smaller volumes), the cost difference does not increase proportionally;

- The role of micro-farm production in exports should be reanalysed, because the majority of fruit and vegetables in Tajikistan are produced through small-scale, family-based production; and

- Rural households have demonstrated high potential in producing agricultural products (fruits and vegetables) in commercial volumes for export.

\subsubsection{Retail Trade and Consumer Services}

The retail trade sector is one of the main drivers of Tajikistan's economy, experiencing impressive growth in the past decade. A significant part of this growth was generated by the private sector; its share of retail and commercial trade turnover was 97.6 percent in $2012 .^{24}$

Table 1. Main Sources of Retail Trade in Tajikistan, 2006 -2012

\begin{tabular}{|l|c|c|c|c|c|c|c|}
\hline & 2006 & 2007 & 2008 & 2009 & 2010 & 2011 & 2012 \\
\hline Retail Shops & 10,328 & 10,571 & 10,959 & 11,905 & 12,080 & 11,528 & 12,119 \\
\hline Catering Enterprises & 2,840 & 3,140 & 2,900 & 2,883 & 2,641 & 2,686 & 2,677 \\
\hline Petroleum Stations / Shops & 706 & 761 & 789 & 862 & 1,026 & 1,013 & 1,079 \\
\hline Retail Markets & 268 & 269 & 280 & 299 & 312 & 306 & 308 \\
\hline Livestock Markets & 54 & 54 & 54 & 54 & 99 & 110 & 107 \\
\hline
\end{tabular}

Source: SART, Basic Indicators of the Trade and Services Sector of the Republic of Tajikistan (SART, 2013)

The number of retail trade enterprises in Tajikistan is consistently growing, as are overall trade volumes (see Table 1 and Figure 12). Retail markets provide jobs for more than 70,000 traders in the country. ${ }^{25}$ The trade sector provides jobs for an estimated 8.9 percent of the total number of employed workers in the country (or 164,800 people in 2009). ${ }^{26}$

24 SART, Basic Indicators of the Trade and Services Sector of the Republic of Tajikistan, (Dushanbe: SART, 2013). In Russian/Tajik.

25 Ibid.

26 SART, Labour Market Situation of the Republic of Tajikistan (Dushanbe: SART, 2010). In Russian/Tajik. http://www.stat.tj (date accessed: December 2013). 
Figure 12. Dynamics of Trade in Tajikistan in Constant 2012 Prices, 2006-2012 (million USD)

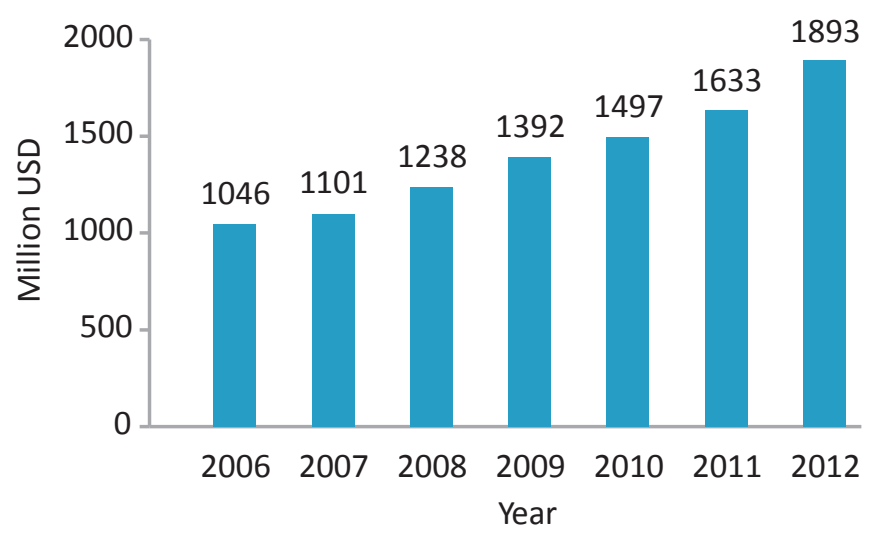

Source: SART, Basic Indicators of the Trade and Services Sector of the Republic of Tajikistan (SART, 2013)

Figure 13. Regional Distribution of Retail Trade Turnover by Type of Market Channel, 2012 (\%)

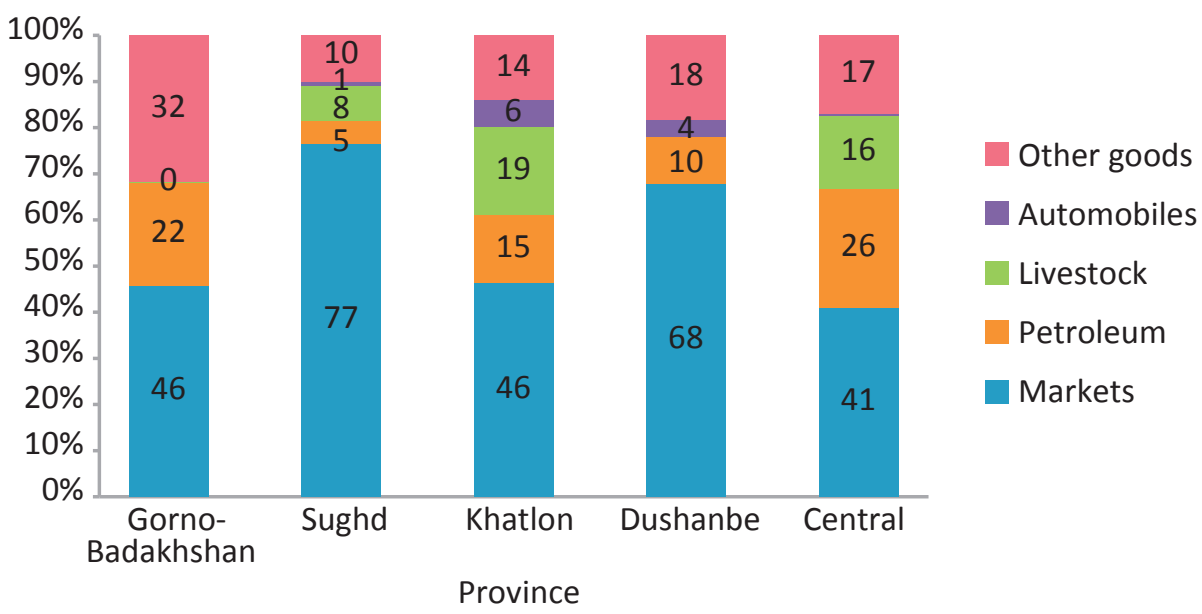

Source: SART, Basic Indicators of the Trade and Services Sector of the Republic of Tajikistan (SART, 2013)

The distribution of traded goods varies from region to region. In Sughd Province, trade through markets makes up the majority of trade (77 percent). Livestock markets make up eight percent of sales; petroleum, five percent; and automobiles, one percent. Other goods make up 10 percent (see Figure 13). Trade activities in Khatlon Province are less concentrated in one channel of trade. However, with 60 percent of all automobiles sold there, the province has higher sales of automobiles than other provinces. Dushanbe, as expected, does not have significant trade through livestock markets, but has higher volume of sales through other markets. The Region of Republican Subordination stands out as a leader in trade of petroleum products; with 40 percent of the country's petroleum traded there due to its proximity to Dushanbe. While essentially rural, Gorno-Badakhshan Autonomous Province does not have significant turnover in livestock trade; just 0.1 percent, since most livestock in the province is either raised for subsistence or bartered.

The paid services sector demonstrated higher growth rates than trade between 2006 and 2012 (Figure 14). Volume of services grew by 112 percent in that period. The share of state 
companies in paid services increased from 18 percent in 2006 to 31 percent in $2012 .{ }^{27}$ However, in paid services to the population, which make up approximately 40 percent of all paid services, the private sector dominates, at 94 percent. Most demand is concentrated in the largest market for paid services, Dushanbe (43 percent). The second largest services market is Sughd Province (29 percent). Other regions make up the balance (28 percent). The impact of the agglomeration of the urban infrastructure is evident in sub-sectors of the service sector. Trade and paid services are more significant in Sughd Province, primarily because of the number of small and medium-sized towns in the province.

\section{Figure 14. Dynamics of Paid Services in Tajikistan in Constant 2012 Prices, 2006-2012 (million USD)}

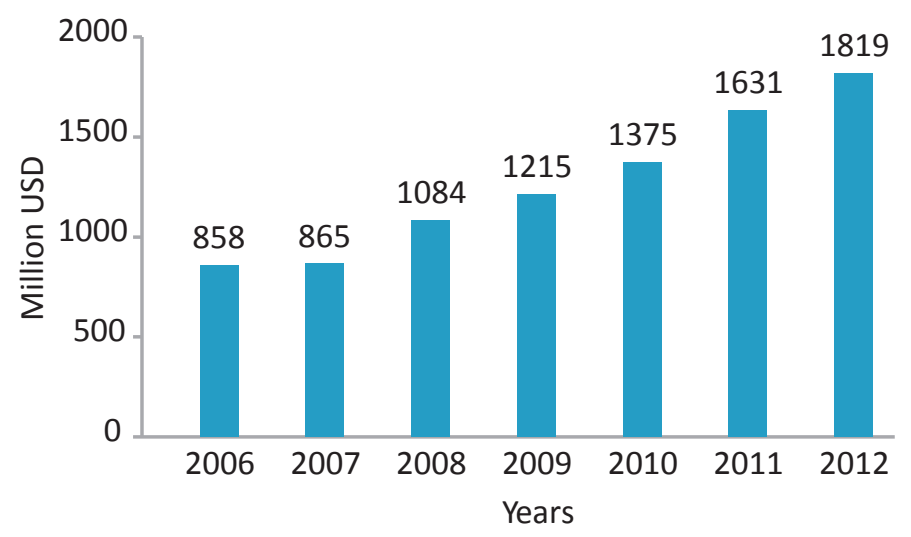

Source: SART, Basic Indicators of the Trade and Services Sector of the Republic of Tajikistan (SART, 2013

\subsubsection{Transport}

The transportation sector includes both freight and passenger transport. MSME share in transport is represented by private entrepreneurs working in the freight transportation of goods from Tajikistan to Russia and Kazakhstan in the north and to Afghanistan in the south. Another area of MSME activity is the transportation of passengers by entrepreneurs in small vehicles in cities and intra-republican transportation between provinces. The main means of transport in Tajikistan is by automobile, due to the landscape and recent problems related to rail transportation through Uzbek territory. There is no detailed information about the distribution of passenger transport services in private and public sectors by means of transport. However, there is official information about the distribution of freight services by different types of transport (see Figure 15).

Overall, freight turnover increased by 43 percent between 2007 and 2011 . The role of the private sector in transportation is significant and saw increases of 68 percent in real turnover. The main source of growth in freight transportation is international transport, in which volumes have doubled. Public transportation includes railroad freight (73 percent in 2011), automobiles (26 percent) and air transportation ( 1 percent) ${ }^{28}$

27 SART, Basic Indicators of the Trade and Services Sector of the Republic of Tajikistan (Dushanbe: SART, 2013). In Russian/Tajik.

28 SART, Statistical Yearbook of Transportation and Communication in the Republic of Tajikistan 2012 (Dushanbe: SART, 2012). In Russian/Tajik. 
Figure 15. Dynamics of Freight Transportation by Types of Transport, 2007-2011 (billion ton-kilometres)

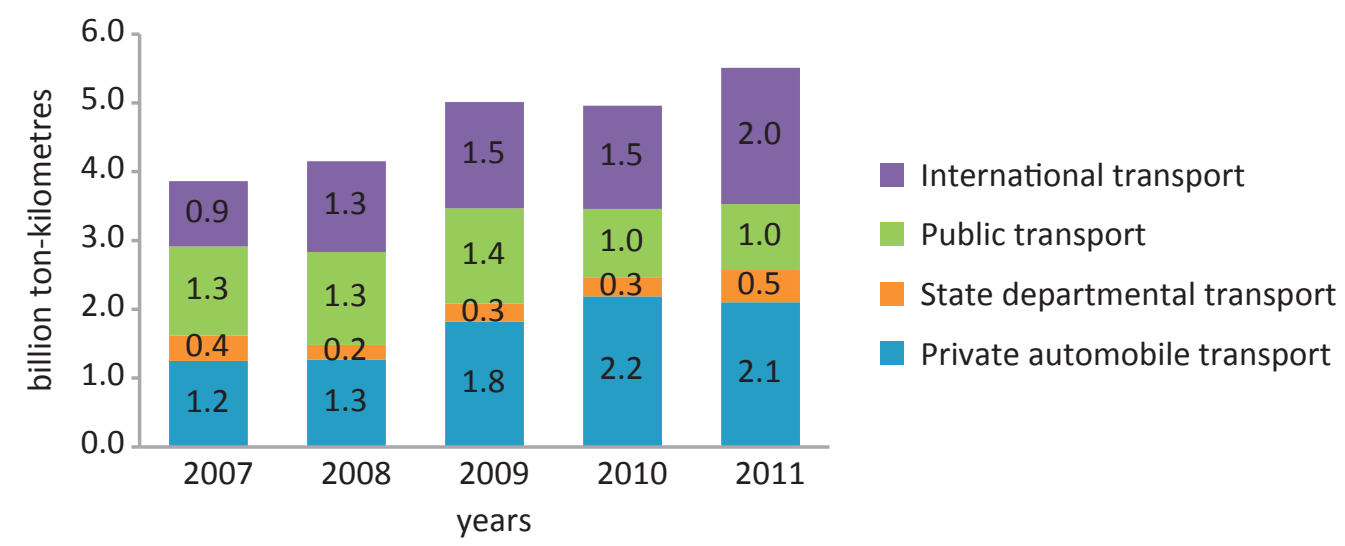

Source: SART, Statistical Yearbook of Transportation and Communication Sector in the Republic of Tajikistan 2012 (SART, 2012).

Passenger transportation is also represented by the turnover of services by different means of transport, measured in passenger-kilometres. As in the case of freight transportation, overall volume saw significant growth of 31 percent (see Figure 16). However, private sector volumes in passenger transportation began to decrease in 2011 and have been stagnating. This stagnation is alarming. High levels of state involvement prevents the growth of private capital in a number of sectors where private MSMEs could more effectively and efficiently operate.

Figure 16. Dynamics of Passenger Transportation by Types of

Transport, 2007-2011 (billion passenger-kilometres)

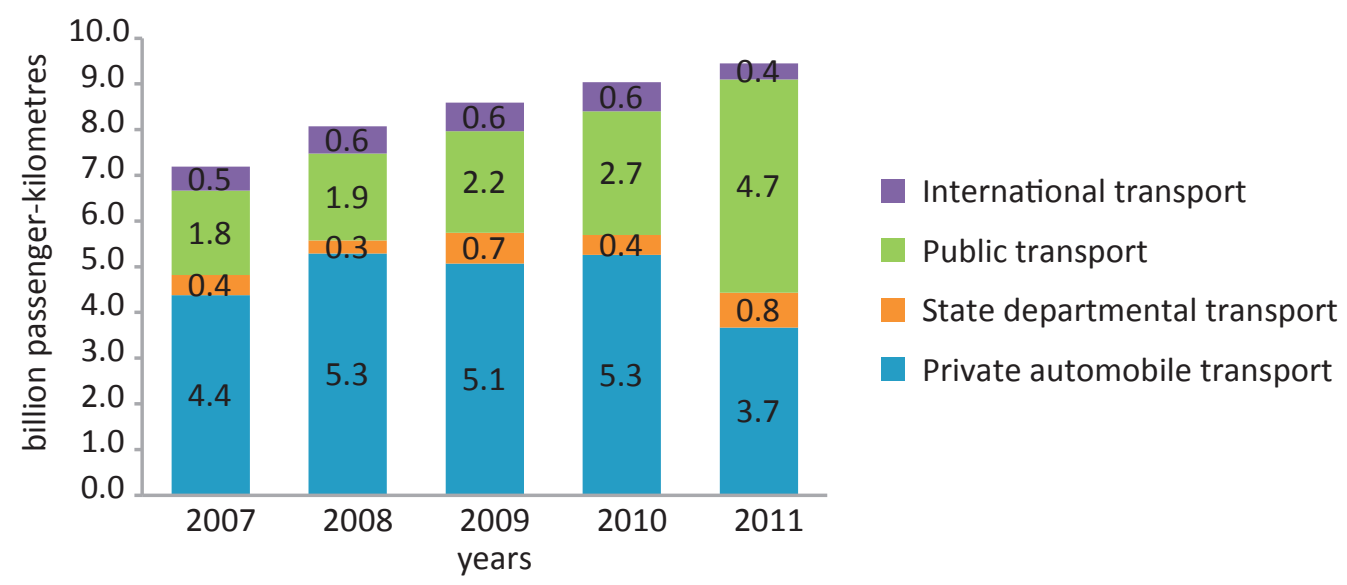

Source: SART, Statistical Yearbook of Transportation and Communication in the Republic of Tajikistan 2012 (SART, 2012). 


\section{Survey of the MSME Sector}

A field survey was conducted of representatives of small businesses across Tajikistan from June to July 2014. ${ }^{29}$ Three growth sectors of the economy linked to MSME development were investigated - agriculture, trade and services and transportation (passenger and freight). This chapter describes the methodology and content of the field study. Sampling methodology is provided in section 3.1 and section 3.2 describes the content of the questionnaire.

\subsection{Sampling Methodology}

Of the three selected sectors, small-scale agriculture is primarily a rural business, and trade and services and transportation are urban enterprises. Therefore two different approaches were developed to select our sample, which included representation from both rural and urban areas. Each area presented its own challenges. The scope of rural small businesses is difficult to define, because any of the 810,000 rural households in Tajikistan could qualify as study subjects. In urban areas, informality and lack of official documentation made it challenging to verify the validity of any list of businesses.

In examining MSMEs, a cluster or 'geographical and sectoral agglomeration of firms, ${ }^{30}$ is a useful unit of analysis. In the survey design, clustering was used to select specific areas in each region to represent selected sectors. Two main categories of clusters were identified - urban and rural. A cluster was defined as a set of business entities with a specific structure (based on technology, production or service cycle and size), concentrated in a certain geographical territory.

\subsubsection{Urban Areas}

The largest cities in Tajikistan, namely the capital city and provincial centres, were naturally selected as urban locations of MSMEs in the trade and services and transportation sectors. Specifically, Dushanbe, Khǔjand, Kulyab and Khorog were selected. Each city was then divided into several sections based on administrative divisions or different geographic locations. For the trade and services sector, areas with an intense concentration of trade and services were identified. For passenger transportation, areas including main transportation routes were selected. For freight transport, areas with former or existing motor-transport depots located near main transport corridors in each city were selected.

Survey respondents were selected through the following process:

- For retail trade and services, an equal number of businesses were identified across each area of the city. In each cluster, supervisors selected an interval for interviewers, depending on the number of enterprises and the target number of respondents for each subsector. Each interviewer received a starting point for each cluster.

$29 \quad$ The Institute of Public Policy and Administration (IPPA) at the University of Central Asia contracted LLC "M-Vector Research" to administer the survey; all field work was administered by them under the supervision of IPPA.

$30 \quad$ Hubert Schmitz, “On the Clustering of Small Firms," Institute of Development Studies Bulletin, 23, 3, (1992): 64-69. 
- For passenger and freight transportation, target numbers of respondents were preliminarily defined for each cluster and sub-sector. The interval for selecting respondents was randomly defined, and a starting point was provided for each cluster.

The final sample of urban entrepreneurs is presented in Table 2, and Figure 17 presents the example of the distribution of respondents in Dushanbe.

Table 2. Final Sample of Urban Respondents

\begin{tabular}{|l|c|c|c|c|c|}
\hline \multirow{2}{*}{ City } & \multicolumn{2}{|c|}{ Trade and Services } & \multicolumn{2}{|c|}{ Transport } & Target Urban \\
\cline { 2 - 5 } & Retail Trade & Services & Passengers & Freight & Sample \\
\hline Dushanbe & $38^{31}$ & 12 & 13 & 12 & 75 \\
\hline Kulyab & 13 & 12 & 13 & 12 & 50 \\
\hline Khǔjand & 13 & 12 & 13 & 12 & 50 \\
\hline Khorog & 13 & 12 & 13 & 12 & 50 \\
\hline Total & 77 & 48 & 52 & 48 & 225 \\
\hline
\end{tabular}

Source: Survey Information

Figure 17. Distribution of Urban Clustered Sample in Dushanbe ${ }^{32}$

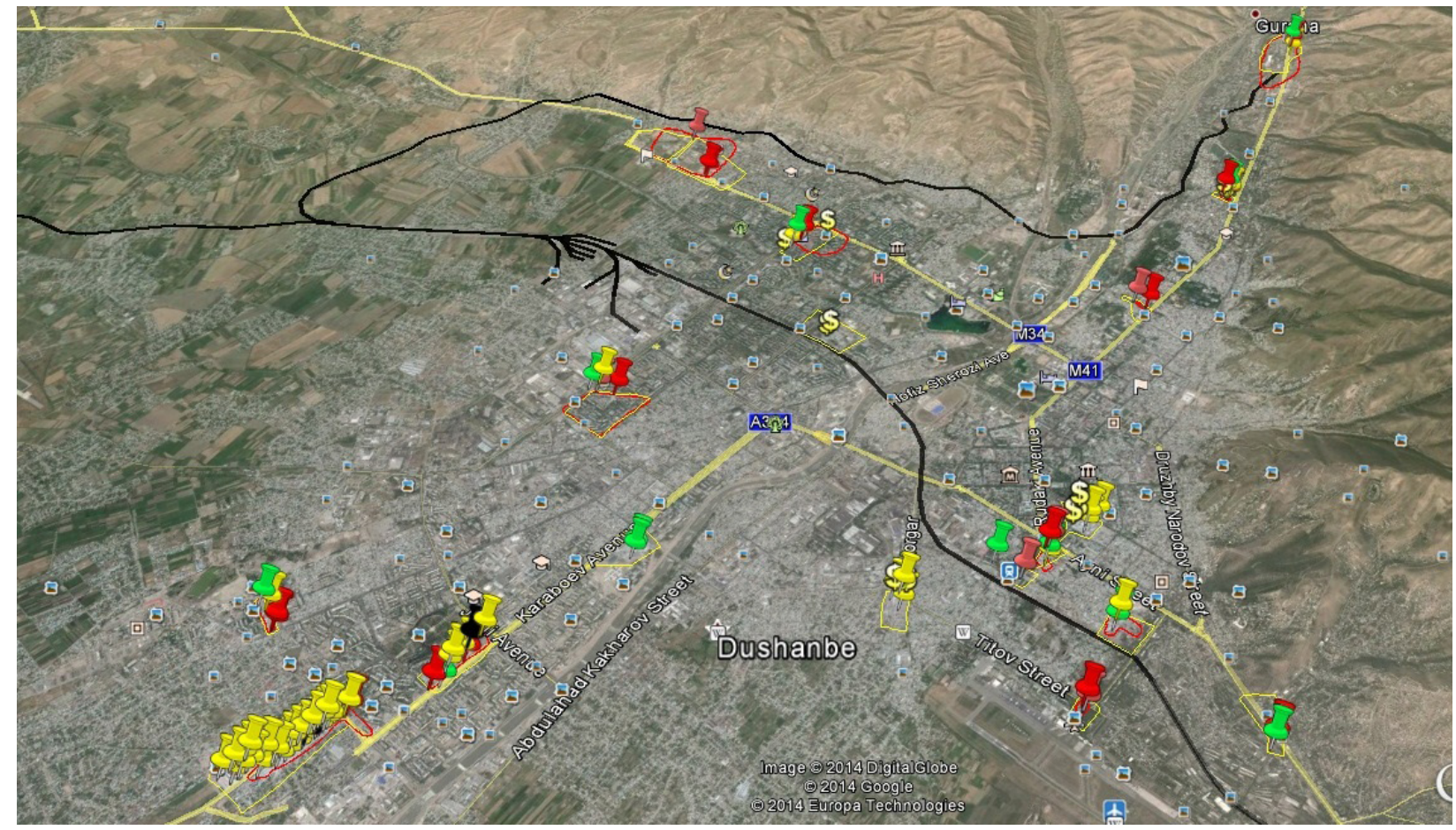

Source: Map Data C2012 Google, Sanborn

31 In Dushanbe a larger number of retail businesses were covered, because additional data was collected from Karvon market, the biggest retail market in Dushanbe with approximately 10,000 trading places. Twenty five additional respondents were covered in this cluster.

32 Yellow pins indicate the location of retail trade and service businesses; green and red pins indicate respondents in the passenger and freight transport sectors respectively. 


\subsubsection{Rural Areas}

To select our sample of rural MSMEs, we first identified a key agricultural product in each province to help identify an area cluster:

- Region of Republican Subordination: Milk

- Khatlon Province: Onions

- Sughd Province: Dried fruit

- Gorno-Badakhshan Autonomous Province: Meat

Next, the district with the highest production of that product was selected in each province:

- Region of Republican Subordination: Hisar district

- Khatlon Province: Bokhtar district

- Sughd Province: Isfara district

- Gorno-Badakhshan Autonomous Province: Shughnon district

Finally, four pairs of villages in each district were selected, based on their (different) distance from the district centre. A pair was randomly selected, from which a target village was then randomly selected for surveying:

- Hisar district: Hisar village

- Bokhtar district: Urtabuz village

- Isfara district: Kulkand village

- Shughnon district: Miyonshar village

Table 3. Final Sample of Rural Households

\begin{tabular}{|l|c|c|c|}
\hline Province & District & Village & Target Rural Household Sample \\
\hline Region of Republican Subordination & Hisar & Hisar & 25 \\
\hline Khatlon & Bokhtar & Urtabuz & 25 \\
\hline Sughd & Isfara & Kulkand & 25 \\
\hline Gorno-Badakhshan Autonomous & Shughnon & Miyonshar & 25 \\
\hline Total & 100 & & \\
\hline & Source: Survey Information &
\end{tabular}

In each village, since agricultural MSMEs are generally household-based, 25 households were selected as a target sample. In this way, 100 households were covered in the rural business clusters. To identify respondents for the household survey within each village, a snowball method was used. First, the territory of each village was divided into four sections (Miyonshar village was divided into three sections because of its particular topography). In each section, survey supervisors, with the help of village leaders, identified a first point of contact to interview; a person engaged in agricultural business in tradable volumes. The interviewed respondent, in turn, identified other agricultural entrepreneurs in their section of the village. The final sample of rural entrepreneurs is presented in Table 3, and Figure 18 presents the example of the distribution of respondents in Kulkand village. 
Figure 18. Distribution of Rural Clustered Sample in Kulkand Village

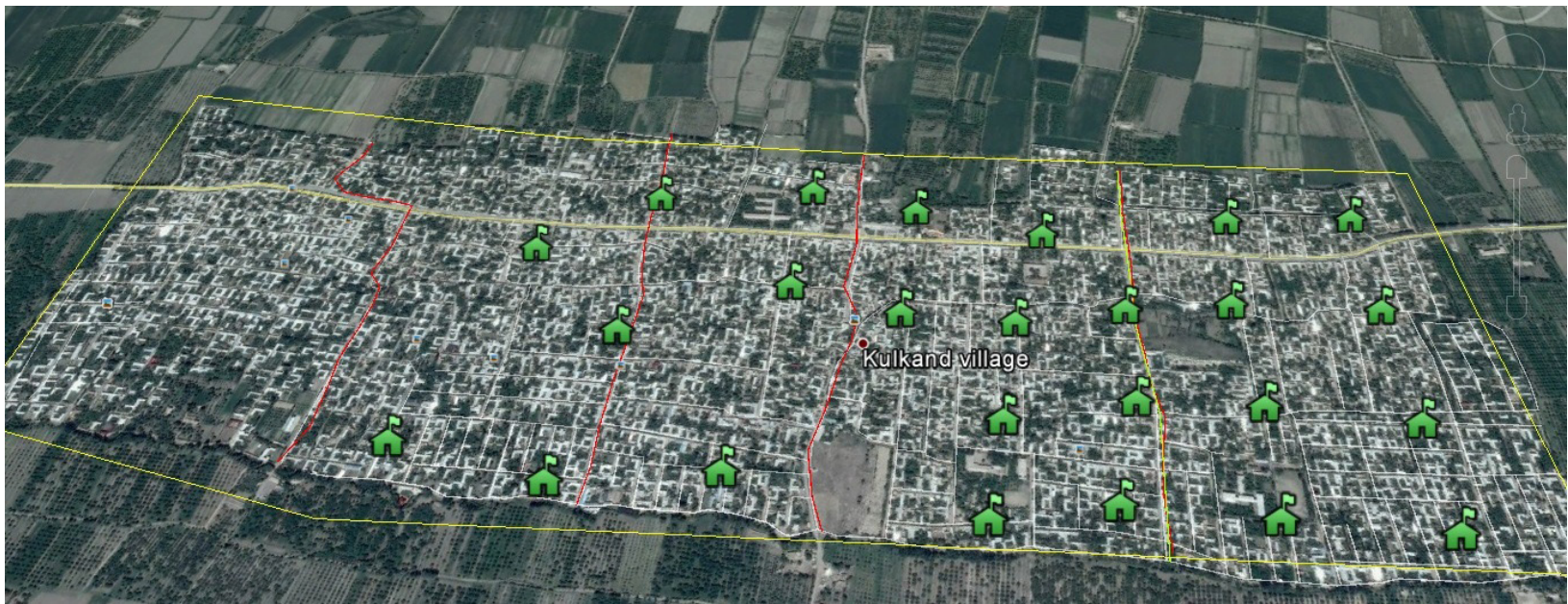

Source: Map Data (C2012 Google, Sanborn

Our sample was not fully representative due to lack of access to a definite population of entrepreneurs. However, these multi-stage random selection procedures to identify and survey both urban and rural entrepreneurs provided cluster-based representative samples for each sector.

\subsection{Questionnaires}

The survey methodology utilised two kinds of questionnaires - an urban individual entrepreneur questionnaire and a rural household questionnaire. Each questionnaire included sections on the characteristics and activities of businesses (see Table 4 for questionnaire sections). The two questionnaires were designed separately; the structure of the questions were standardised as much as possible, but took into account the different nature of business for urban entrepreneurs and farmers. The questionnaires were developed in Russian and translated into Tajik. Questionnaires were first piloted to ensure that the content and translation was adequate and the survey administrators were comfortable with them.

Table 4. Questionnaire Sections

\begin{tabular}{|c|c|c|l|}
\hline \begin{tabular}{|l|l|} 
Small Business/Individual Entrepreneur \\
Questionnaire
\end{tabular} & \multicolumn{2}{l|}{ Household Questionnaire/Small Business Farm } \\
\hline No. & Section & No. & Section \\
\hline I & Personal Information & I & Household Information \\
\hline II & Information on Business & II & Dwelling Conditions and Business Assets \\
\hline III & Business Assets & III & Land Characteristics \\
\hline IV & Investment and Innovations & IV & Crop Harvest \\
\hline V & Loans and Savings & V & Crop Production Expenses \\
\hline VI & Use of Labour Force & VI & Livestock Availability \\
\hline VII & Information for Business & VII & Livestock Products \\
\hline VIII & Market Information & VIII & Livestock Production Expenses \\
\hline IX & Barriers to Growth for Business & IX & Loans and Savings \\
\hline X & Taxes & X & Use of Labour Force \\
\hline & & XI & Information for Business and Investments \\
\hline & & XII & Market Information \\
\hline & & XIII & Barriers to Growth for Business \\
\hline
\end{tabular}




\section{Entrepreneur Profile and Factors Impacting MSME Growth}

This chapter provides an overview of the surveyed sample of MSME sectors across Tajikistan. Section 4.1. describes the profile of sampled entrepreneurs, with a focus on the personal characteristics of urban and rural micro-entrepreneurs. The remaining sections describe the main determinants of business growth, namely, capital, labour, information and decisionmaking. Barriers to MSME growth are also discussed.

\subsection{The Profile of Entrepreneurs in Tajikistan}

\subsubsection{Urban Entrepreneurs}

Two hundred and twenty five entrepreneurs working in retail trade and services and passenger and freight transportation in four cities were surveyed. The majority of respondents are individual business owners (80 percent), primary owners and co-owners (14 percent). Of the balance, a few work in family businesses ( 3 percent) and as hired managers ( 3 percent).

Most entrepreneurs (82 percent) fall into the most productive age group of 20 to 50 . A small proportion is younger than 20 years old ( 4 percent) and the balance (14 percent) are between 50 and 70. Forty four percent of respondents have worked in their current business for between one and five years and ten percent joined their current business within the last year. Just over a quarter have worked in their current business for between five and ten years (27 percent), and almost a fifth for over ten years (19 percent) (See Figure 19).

\section{Figure 19. Age and Duration in Current Business of Urban Entrepreneurs}

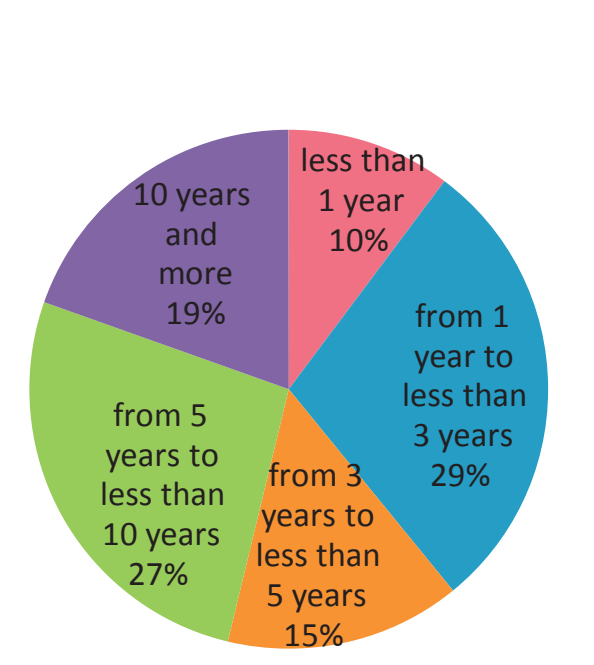

Time Spent Working in Current Business

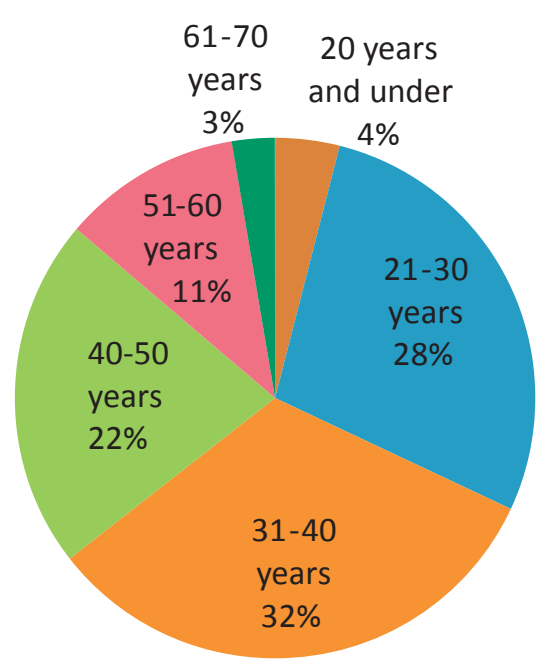

Age of Entrepreneurs

Source: Survey Data

While 70 percent of surveyed urban respondents are male, and only one woman is the owner of a business in the transportation sector, over half the entrepreneurs in retail trade and services are women (53 percent). With regard to marital and family status, 74 percent of sur- 
veyed urban entrepreneurs are married. The majority have children (76 percent) and some have grandchildren ( 7 percent).

Most surveyed urban entrepreneurs are educated. A third graduated with a diploma of higher education (34 percent). Up to 8 percent attended, but did not finish, university. Over a fifth finished specialised secondary education ( 22 percent) and 28 percent graduated from secondary school. Only 8 percent have a basic secondary education ( 9 years of school) and one person has a post-graduate degree. Of those who attended colleges and universities, the most popular specialisations were technical sciences (19 percent), economics and business (15 percent) and teaching and education (11 percent).

When asked about what motivates them to work in their business, 40 percent of respondents mentioned profit and close to a third stated that it was the only way to earn an income (29 percent). Other motivations include realising personal potential (13 percent), working for societal welfare (11 percent) and continuing family business traditions (7 percent).

Almost half of the business entities surveyed work by patent system (48 percent). Of the remaining half, 14 percent work with certificates, 3 percent work under a license and 6 are limited liability companies. As many as 29 percent of respondents have not officially registered their enterprise (see Figure 20).

The majority of respondents underestimated business turnover, perhaps due to apprehension of tax liabilities. As many as ninety percent of urban entrepreneurs indicated a turnover of less than $\$ 10,000$ a year; eight percent reported a turnover of between $\$ 10,000$ and 20,000 . The balance of two percent indicated an annual turnover more than $\$ 20,000$.

Short term expectations of turnover in the current year vary. As many as 38 percent of respondents anticipate lower turnover than they had in 2013. However, 32 percent are optimistic about turnover in 2014, and one quarter expects the same level. Some respondents (5 percent) are still unclear in their expectations.

Figure 20. Form of Registration of Urban MSMEs

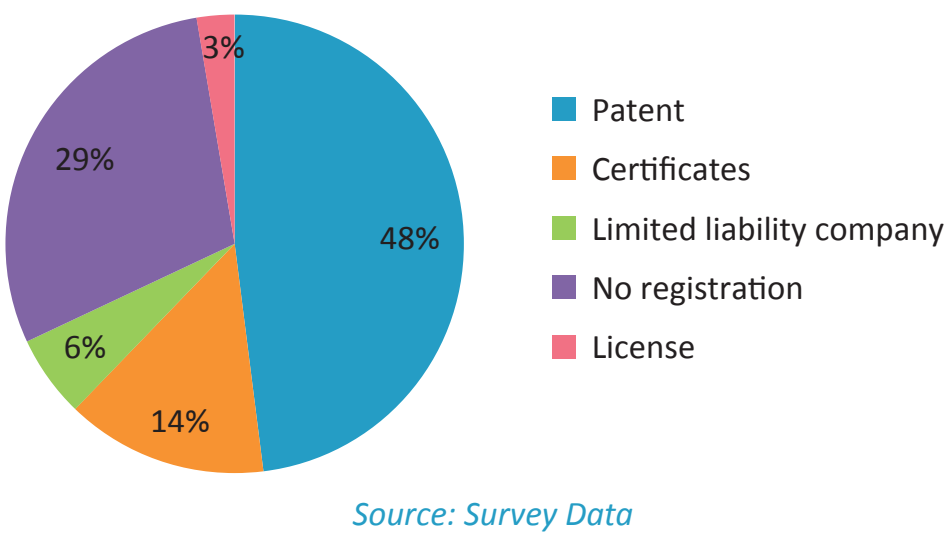

Long-term expectations are more clearly optimistic, with 42 percent of respondents anticipating growth, expansion or diversification of their business. About a quarter do not anticipate any financial changes (23 percent) and only 12 percent expect a worsening of their situation. A fifth found the question difficult to respond to (22 percent). 


\subsubsection{Rural Entrepreneurs}

Farmers were surveyed from 100 rural households across the country. Of these, 10 percent are individual entrepreneurs, 45 percent are dekhan farmers and the balance are rural households without registration ( 45 percent). The head of household was defined as an entrepreneur. The majority of household heads are men (89 percent), with an average age of 55 years old. The balance of female household heads (11 percent) had a higher average age of 63.

\section{Figure 21. Age of Rural Entrepreneurs}

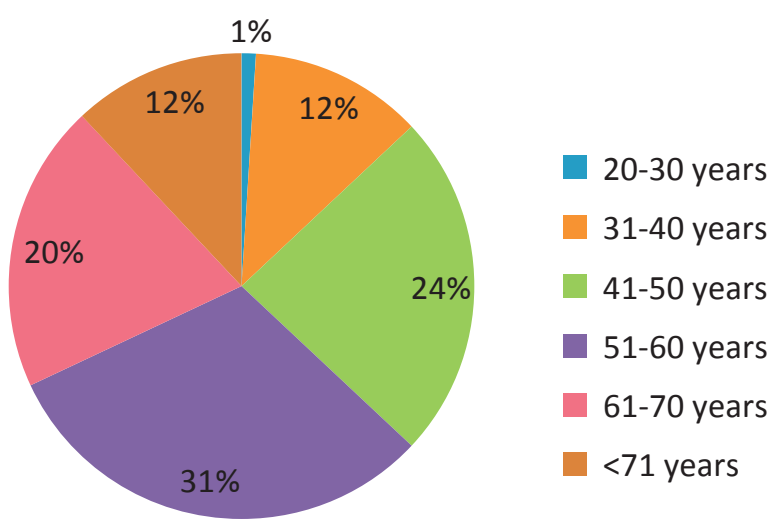

Source: Survey Data

The age profile of rural entrepreneurs differs from that of the urban sample. One third of respondents are older than 61 years of age (32 percent). Over half the farmers surveyed are aged 41 to 60 years old (55 percent), and only 13 percent are under the age of 40 (see Figure 21).

Most surveyed farmers are married (83 percent). Of the balance, seven percent live with a partner in an unregistered relationship, nine percent are widowed (mostly women), and only one person reported not being married or in a relationship.

\subsection{Capital}

Capital assets for business operations are crucial for MSME growth.

\subsubsection{Key Urban Capital Assets}

For urban entrepreneurs, key assets include work space (including spaces to service clients, warehouses, garages and parking areas); vehicles and equipment; and savings and credit.

Spaces to service clients include any type of room or building where client trade and services needs are met. In our urban sample, 55 percent of entrepreneurs, most in trade and services (97 percent), have access to such spaces. Most rent spaces (78 percent), the rest own premises (17 percent) or obtained their facility during the privatisation process ( 3 percent) or as a legacy. Almost half the spaces to service clients have been used for less 
than three years (47 percent), and a third have been used for more than five (31 percent). The average size of business spaces is 25 square metres. Nine percent of respondents use warehouses, with an average size of 27 square metres, the majority of which are rented, owned or obtained during privatisation (71 percent). Garages (accessed by just five percent of respondents) and parking places (accessed by six percent) are primarily used by entrepreneurs in the transportation sector.

Vehicles are another important asset of small businesses, particularly in the transportation sector; most reported vehicles belong to respondents from that sector ( 90 percent). Among respondents, 31 percent own their car (69 respondents). Of these, 59 percent work in the transportation sector. Most passenger automobiles were purchased (eighty seven percent), with two thirds purchased in the last three years. About a quarter of respondents reported having trucks (twenty three percent), and nine percent own a minibus.

Equipment for trading purposes includes information and communication technology, refrigerators, shop-windows and counters, and is used by 17 percent of urban respondents. Most work in trade and services (98 percent), and of these, the majority work in trade (63 percent). Almost all respondents have mobile phones, which they use for work ( 90 percent), and a fifth (20 percent) own personal computers and laptops.

Savings and credit are forms of capital assets for small urban businesses, with 41 percent of respondents reporting their use. Most savings are under $\$ 10,000$. The most popular form of savings is cash held by the owner (75 percent). Depositing savings in banks is not popular (14 percent). Another form of capital is lending money to a people; as many as 40 percent of urban entrepreneurs report engaging in money lending, in amounts similar to the size of savings.

\section{Figure 22. Urban Sources of Credit}

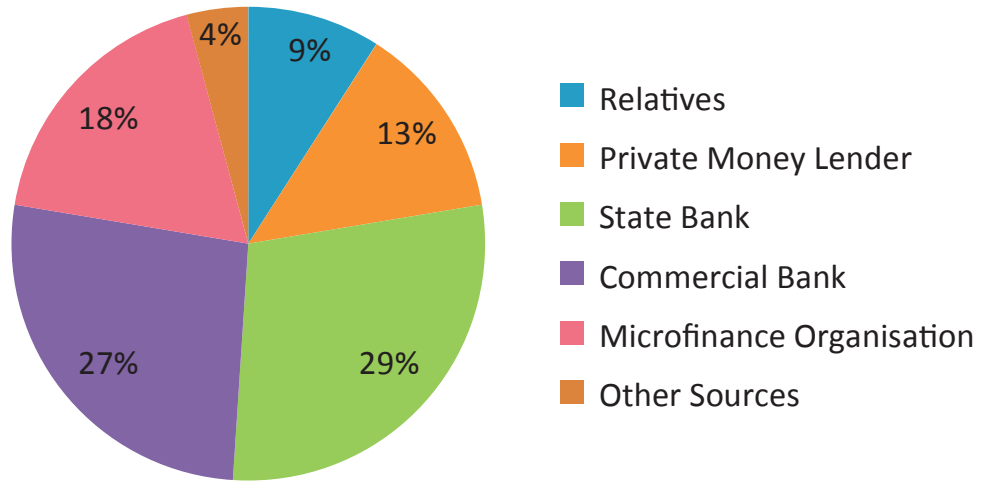

Source: Survey Data

Reliance on credit is widespread among small businesses in urban areas. Almost half the respondents (45 percent) reported using crediting from various and multiple sources. Ten percent have two lines of credit, six percent have three and three percent have four lines of credit. The average credit amount is $\$ 6,400$, with a high average interest rate of 29 percent. Most lines of credit were obtained in the last two years (see Figure 22). 
For most of credit (55 percent), collateral involves conditions attached to mortgages. It also includes homes (57 percent), land (13 percent), vehicles (10 percent), other personal belongings (8 percent) and jewelry (6 percent).

\subsubsection{Key Rural Capital Assets}

For rural entrepreneurs, key business assets include homes, land, livestock, machinery and savings and credit.

Most rural respondents live in houses (82 percent) and the balance lives in apartments. Most homes have been owned for an average of 27 years. Almost half the respondents inherited (45 percent) and the other half built their house (44 percent). Very few respondents received ( 7 percent) or privatised ( 4 percent) houses. Less than half the houses owned by respondents are connected to clean water ( 45 percent) and almost all are heated by stoves (97 percent).

Among sampled households, agricultural land was identified as a key asset. The majority use land on an individual household basis (68 percent). The balance use land on a collective basis or rent land. The average size of plots is 1.92 hectares, but there are significant deviations. Almost all respondents use irrigated arable lands (93 percent) and 76 percent of them have official permission to use the land. As many as 77 percent of farmers pay to use the land. Only 55 percent of all rural respondents want to increase the amount of land they have. Most prefer using land on a household basis (79 percent), 11 percent prefer renting and 10 percent prefer collective ownership. 71 percent of responding farmers are satisfied by the quality of their land. Farming requires irrigation; 75 percent of irrigation is done through canals and 17 percent is through water pumping systems.

Livestock is also an important resource in rural areas. The most common animals are cows, with 89 percent of households reporting ownership. On average, each household has 2.2 cows. Other livestock is less common; 36 percent of famers own sheep, with an average of 12 sheep per household and other livestock are not owned in significant numbers.

Rural farmers do not generally own agricultural machinery. Over half have access to a tractor (59 percent), but most rent them (52 percent). Only seven percent of farmers privately own tractors and six percent have a micro-tractor. With regard to other equipment, 10 percent report access to rented mowers, 22 percent to rented harvesters and 15 percent to rented and owned ploughs.

Cash savings are another resource used by rural farmers (72 percent). As with urban entrepreneurs, banking savings is not popular (only 6 percent). The amounts of cash savings and savings deposited in banks are similar, with average amounts of $\$ 400$ and $\$ 450$ respectively. 
Figure 23. Rural Sources of Credit

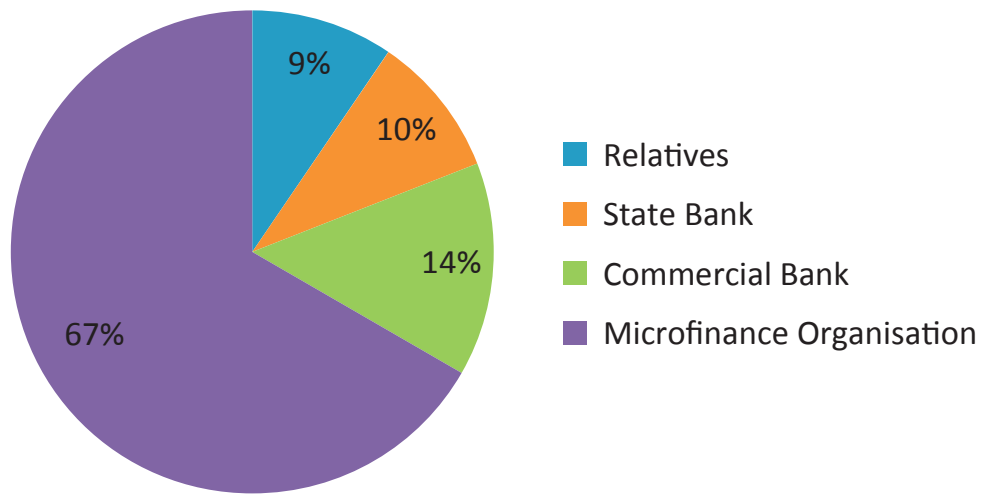

Source: Survey Data

Credit is a less accessible resource in rural areas than in urban areas. About a quarter of rural respondents reported having credit obligations (24 percent). Of these, nine percent reported having two lines of credit, six percent had three credits and three percent had four.

The main source of credit for rural farmers is microfinance organisations (see Figure 23). The average credit line is lower than that of urban businesses at $\$ 2,400$.

Notably, interest rates are higher in rural areas, at 30.6 percent. The majority of reported credit lines were obtained in 2013 and 2014 (55 percent). In contrast to urban respondents, only 19 percent of rural respondents reported that their collateral involves conditions attached to mortgages.

\subsection{Labour}

\subsubsection{Labour Trends in Urban MSMEs}

The majority of urban entrepreneurs in trade and services and transportation are self-employed and do not hire labour and family members (71 percent). About a fifth engages family members in their business, with an average of two family members in each business (22 percent). Just 14 percent hire labour, with an average of three employees. Only 6 percent hire both family members and hired labour simultaneously.

Almost all self-employed urban entrepreneurs want to work more (94 percent). Their declared income is low at approximately $\$ 470$ a month, and 61 percent are the main breadwinner in their family. To augment income from their business, over a quarter report working at night (28 percent). For almost half of them (47 percent), their educational background is not related to their line of business, for 28 percent, it is directly related and for 21 percent, it is somewhat related.

Hired labour is primarily used in trade and services, in customer service and small temporary assignments (see Figure 24). Most hiring is done through oral agreements (70 percent). Payment is made on a per assignment basis ( 48 percent), by time worked ( 33 percent) or in 
a lump sum (19 percent). ${ }^{33}$ Notably, 45 percent of salaries are paid monthly and 42 percent are paid daily, indicated two main types of work; consistent work for a regular monthly salary and occasional one day assignments with immediate payment.

Hired workers are found through personal recommendations (41 percent), tapped from previous work experience (28 percent) and through advertising (22 percent). Salary is determined by speed and quality of work. Over a quarter of entrepreneurs agreed on salary with the worker on an individual basis (29 percent).

Figure 24. Use of Hired Labour in Urban MSMEs

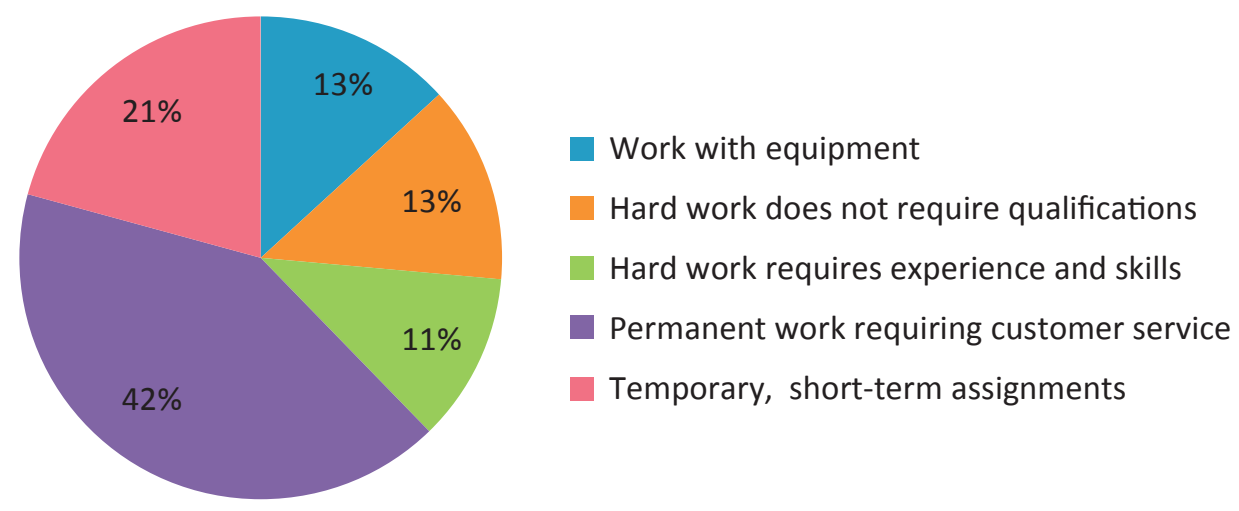

Source: Survey Data

A quarter pays the average salary in the sector (26 percent). In some cases, relatives ( 5 percent) and permanent workers ( 3 percent) receive higher pay. Over a third of respondents prefer hiring experienced workers, regardless of age (34 percent). A quarter prefers younger workers of up to 30 years of age (25 percent). Women were preferred by 21 percent, over men, who were preferred by just 13 percent. This might be explained by the high prevalence of women in trade and services, a main employer in our urban MSME sample.

In half the cases, entrepreneurs did not train their workers because training was not necessary for job performance ( 49 percent). In other cases, they lacked the time or the skills to train their employees (14 percent each). If entrepreneurs did train workers, they focused on customer service (34 percent), working with equipment ( 26 percent) and safety ( 21 percent).

Family members engaged in business play a different role than hired labour since they engender a higher level of confidence and trust (see Figure 25). Most, but not all, receive pay for their work (71 percent). Working in a family business is considered part of family work. Most respondents trust immediate family members more than other relatives ( 94 percent). However, other relatives are hired because they are thought to work better (38 percent) and be more reliable ( 26 percent) than other hired labour. They are also hired due to a sense of obligation by the entrepreneurs to provide financial support (31 percent).

33 Salaries were classified into three categories: payment for a particular assignment (e.g. loading and unloading goods); payment by time worked by employee (e.g. selling produce in a shop); and a lump sum base salary paid for a certain phase of work (e.g. for each stage of home repair, such as cleaning and painting ). 
Figure 25. The Role of Family Members in Urban MSMEs

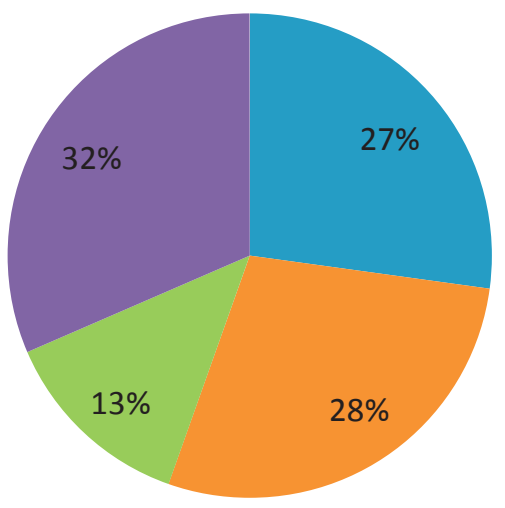

Work requires special skills and experience

Work requiring accountability for results

Overseeing employees

Protection of property, goods and valuables

Source: Survey Data

There is usually no written contract between relatives; only 19 percent of entrepreneurs reported having contracts with family members. Most family members receive a salary (53 percent), some are paid by time worked (18 percent) and the rest receive a lump sum (28 percent). The majority of entrepreneurs provide monthly salaries to family members (71 percent), which vary based on average salary in the sector (45 percent of cases), speed and quality of work (26 percent) and individual agreements (22 percent).

As with unrelated workers, experienced family members are preferred regardless of age (43 percent). However, young men are preferred over women by 29 percent of entrepreneurs compared to 8 percent, and young workers up to the age of 30 are preferred to experienced workers over 50 (13 percent and 8 percent respectively). Almost half the urban entrepreneurs reported training relatives to work in their business ( 47 percent). The remaining half did not because training was not necessary for them to successfully do the job (59 percent). A quarter of respondents who engaged relatives (24 percent) reported that there is inside information they do not want to share with other people. In 39 percent of these cases, entrepreneurs share this information with both immediate family members and other relatives, and just 10 percent only share this information with immediate family members.

In conclusion, urban entrepreneurs use a combination of hired labour and family members, both immediate and extended, as needed and prefer working with relatives than with hired labour. Relatives and hired labour usually play different roles and have different work and payment agreements. Training on the job is not widespread; just half the respondents who used hired labour and relatives invest time and other resources in training.

\subsubsection{Labour Trends on Rural Farms}

Rural enterprises require higher investments of labour than urban enterprises, due to labour-intensive tasks and low access by farmers in Tajikistan to agricultural machinery. The surveyed farmers have an average of 16 years experience in farming. In 73 percent of cases, farming is the main source of income for the family. Almost all farmers are ready to work more ( 90 percent) and 30 percent continue working at night. One third of respondents report that farming is potentially harmful to their health due to dangerous equipment, heavy loads and chemical substances (32 percent). For the majority of farmers, their educational background does not relate to their work (65 percent); educational background only relates directly to farming for 12 percent of respondents. 
Rural agriculture is more labour intensive than urban enterprises and requires the involvement of more hired labour and family members; 80 percent of all farmers reported engaging both hired labour and family members. As many as forty percent of surveyed households reported using hired workers, with an average of eight per household. Almost all households reported engaging family members in farming (96 percent), with an average of four people per household.

Hired labourers primarily do hard, unskilled manual labour (55 percent) and hard skilled manual labour (22.5 percent) and operate agricultural machinery (22.5 percent). Labour is hired based on recommendations of friends, neighbours and relatives (43 percent), previous work experience (28 percent) and on the local market (25 percent). Almost all labour is hired with oral agreements, not written contracts.

Payment per assignment is the most popular form of payment (60 percent), wage for time worked is used in 32.5 percent of cases, and a lump sum is provided by 7.5 percent of famers. Daily payments are typical for agricultural work (80 percent). Salary is determined based on individual agreements and speed and quality of work (32 percent each), and average salaries in the sector (20 percent). Regular workers receive higher salaries (12 percent).

When hiring, respondents prefer young workers up to 30 years of age (37 percent), experienced workers regardless of age (32 percent), and men (15 percent) more than women (10 percent). More than half the farmers declared that hiring workers is not a problem (58 percent). However, 24 percent report hiring problems at the peak of the agricultural season and 11 percent report having critical difficulties finding good workers. A small proportion reported increasing salaries when faced with labour shortages.

Just 38 percent of farmers surveyed train their workers. In most cases, training is unnecessary for the workers to do their job (62 percent). Those that do provide training focus on skills to optimise work (53 percent), safety (29 percent) and land protection (18 percent).

Immediate family members and other relatives are usually trusted more and assigned tasks requiring special skills and experience and accountability (see Figure 26). The most important reasons for hiring relatives are their better performance compared to hired workers (51 percent), being able to assign them more responsibility ( 24 percent) and the obligation to financially support extended family members (21 percent).

Figure 26. The Role of Family Members in Rural MSMEs

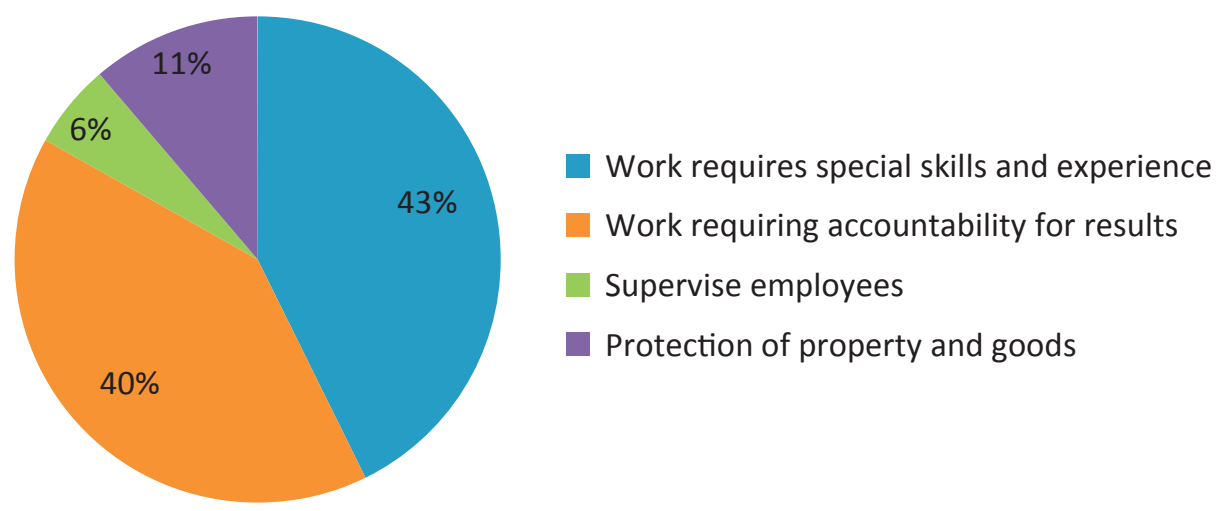

Source: Survey Data 
Immediate family members typically do not receive direct payment for work (81 percent). Work agreements are usually made orally. For relatives being compensated, payment per assignment is most preferable ( 40 percent), time-based wages are used by 26 percent of responses, and a lump sum is made by 34 percent. Daily salaries are paid in 36 percent of cases, monthly salaries in 30 percent and weekly salaries in 5 percent of cases. Salary is determined by speed and quality of work (46 percent), with relatives receiving higher rates than other hired labourers (22 percent). In some cases, relatives who are regular workers receive higher rates (16 percent) than other hired labour. Some salaries for relatives are based on individual agreements (16 percent).

Rural entrepreneurs prefer engaging family members who are young, up to 30 years of age (32 percent), experienced workers regardless of age (27 percent), experienced workers up to 50 years of age (11 percent), men (19 percent) and women (10 percent).

Only 17 percent of farmers provide on-the-job training to their relatives. In most cases, training is not required (85 percent). If training does occur, farmers focus on how to optimise work (35 percent), animal protection (25 percent), work safety (20 percent) and land protection (20 percent).

Rural enterprises rely on more labour than urban enterprises. Like urban entrepreneurs, farmers assign different roles to hired labour and family members, with family entrusted with tasks requiring special skills and more responsibility. Training is not popular as farmers assume that workers are skilled enough to do most agricultural work.

\subsection{Information and Decision Making}

\subsubsection{Urban Sources of Information}

For urban entrepreneurs, the following channels of information are most important: close contacts such as neighbours, colleagues and friends (31 percent), family members ( 25 percent), television (13 percent), the Internet (11 percent), radio ( 6 percent) and newspapers ( 6 percent).

Figure 27. Important Information for Urban MSMEs

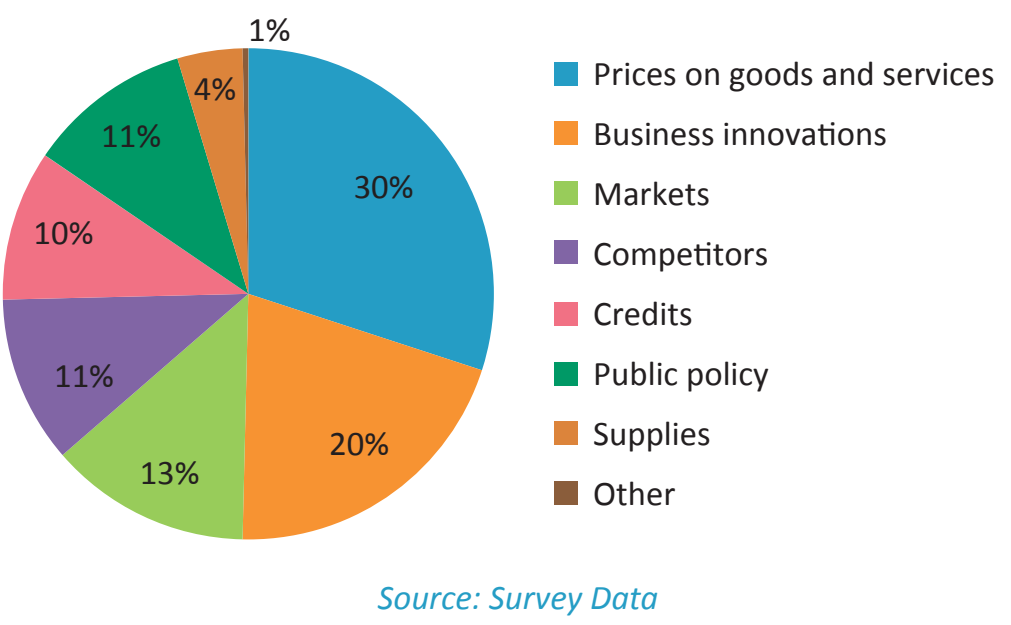


The majority of urban entrepreneurs need information on prices, markets and innovations in business (63 percent). They also find other information on competitors, credit and public policy useful (see Figure 27).

Urban entrepreneurs rely on trusted sources of information: close contacts and family members (36 percent), experienced businessmen (28 percent) and business partners (20 percent). Media channels are used, but are trusted less.

In making business decisions, urban entrepreneurs rely on past business experience (32 percent), and the opinions of family members (21 percent), close contacts (15 percent) and business partners (12 percent).

\subsubsection{Rural Sources of Information}

Figure 28. Important Information for Rural MSMEs

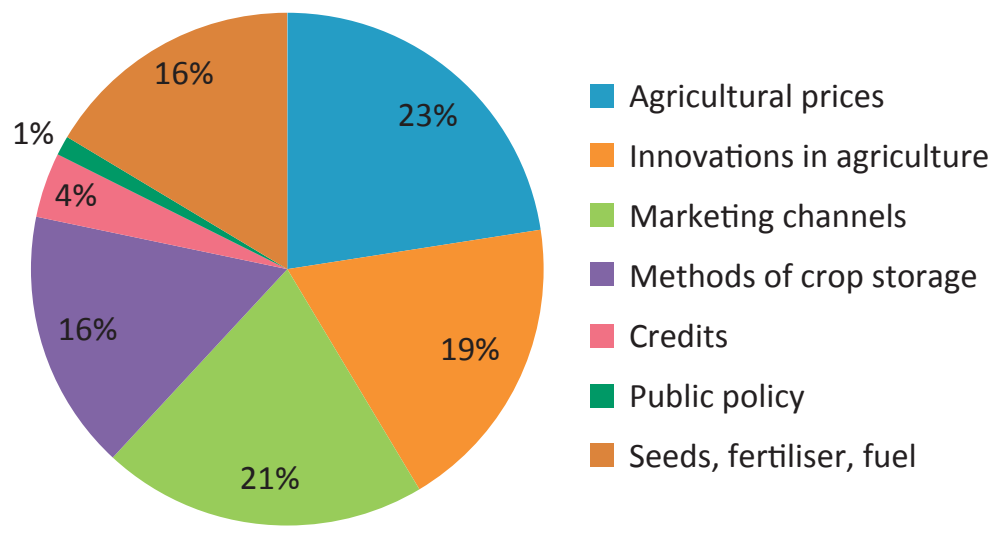

Source: Survey data

For rural farmers, the following sources of information are important: close contacts (30 percent), family members (24 percent), television (20 percent) and local non-governmental or community organisations (10 percent).

Farmers need information related to storing and selling their products, specifically on prices and marketing (60 percent). Information related to improving production, including supplies and innovations, is also considered useful (see Figure 28).

When gathering information, farmers trust more experienced farmers in the community (33 percent), the head of the Jamoat ${ }^{34}$ (18 percent), active community members (18 percent), suppliers of agricultural inputs such as seeds, fertilisers and fuel (16 percent) and businessmen and contractors purchasing agricultural products (12 percent).

As with urban entrepreneurs, when making business decisions, rural farmers rely primarily on past experience (33 percent) and the opinions of family members (26 percent) and close contacts (25 percent).

34 Jamoat is the lowest administrative division, similar to municipalities. It typically includes two or three villages. 


\subsection{Barriers to Growth}

The surveyed entrepreneurs were asked to select three most important barriers to the growth of their MSMEs. Urban entrepreneurs identified the following:

- Market competition (32 percent),

- Low demand for goods and services (21 percent), and

- High taxes (19 percent).

Rural entrepreneurs described the following obstacles:

- Problems with irrigation (25 percent),

- Access to markets (23 percent),

- State interventions (17 percent), and

- High taxes (10 percent).

Entrepreneurs were also asked about their perceptions of the broader institutional environment, including the economic environment, rule of law, trust of state bodies and the court system, and access to finance. For each question, respondents answered on a scale of 1 (strongly disagree) to 5(fully agree) (see Figure 29).

The majority of respondents positively assessed the following components of the institutional environment for small businesses:

- Economic opportunities (45 percent) ${ }^{35}$,

- State influence on the business (57 percent),

- Sufficient level of access to credit (50 percent), and

- Trust of the court system (52 percent).

Notably, only 12 percent positively assessed corruption levels. Most of the remaining responses are located in the middle of the scale ('probably agree') and are more neutral in character.

Urban entrepreneurs were also interviewed about taxes. The majority deal with the tax system independently ( 72 percent). However, only about a third ( 32 percent) stated they understand the tax system well and one third also expressed difficulties understanding the tax administration. The majority of respondents (54 to 58 percent) noted that there have been no significant changes or improvements when assessing the tax rate, tax base and tax period. Entrepreneurs spend a lot of their time in contact with tax authorities; about half spend up to one week per year (48 percent), while a quarter spend up to one month and the rest, even more time. In general, half the respondents do not have problems with tax authorities (54 percent), while about a third is in constant or temporary conflict with tax authorities (30 percent).

$35 \quad$ 'Tend to agree' and 'fully agree' were counted as positive responses. 
Figure 29. The Institutional Environment of Urban and Rural MSMEs

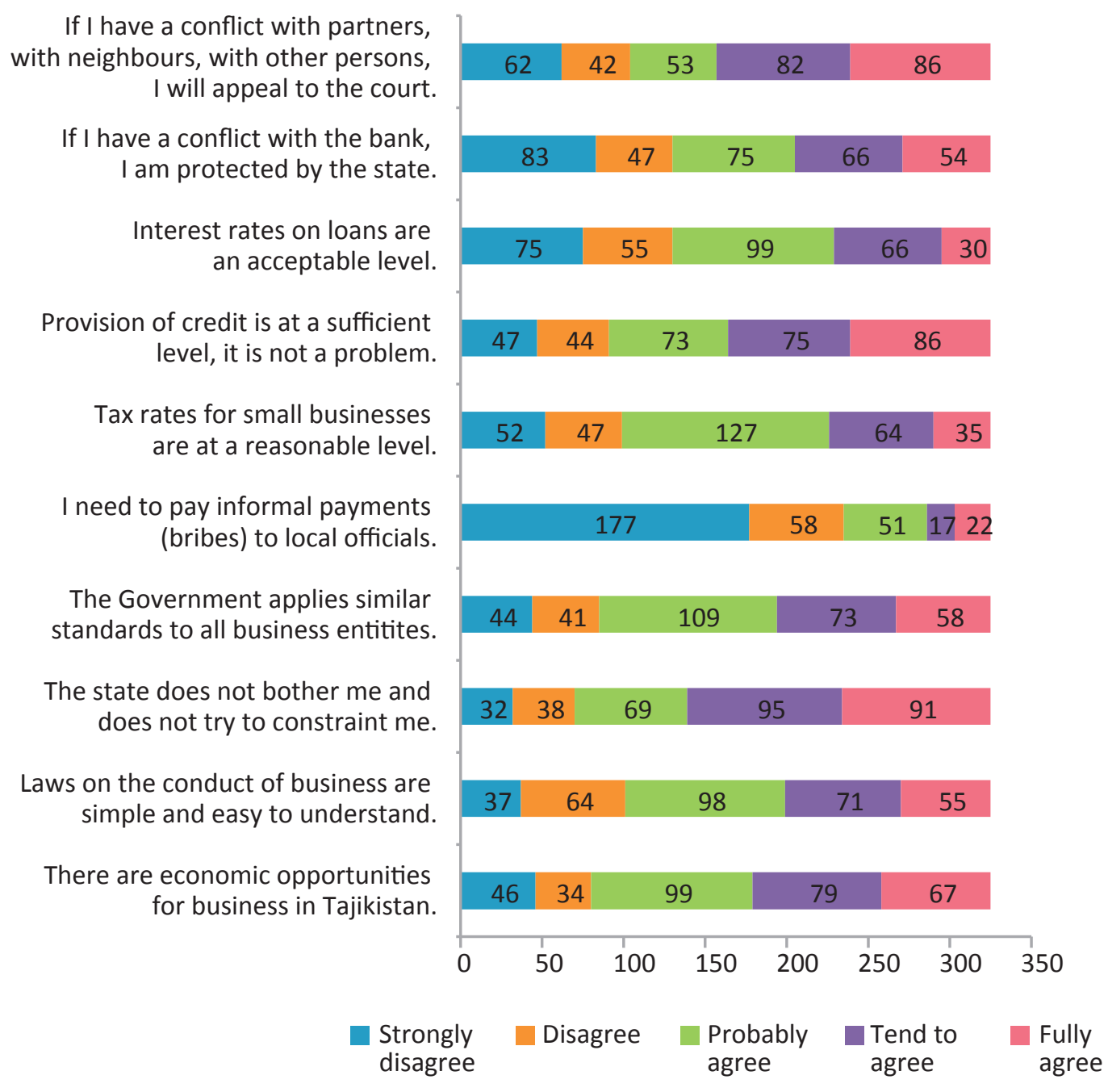

Source: Survey Data

\section{Factors Shaping Investment Performance of MSMEs}

Small businesses often lack of resources. Investments in business development are an important driver of business viability and growth. One third of urban respondents reported investing in business development (33 percent). The majority of investments were under $\$ 10,000$ (89 percent), and most were likely to be well below that amount. The majority of entrepreneurs are generally pleased with the results of their investment; 37 percent report a successful decision, another 43 percent think the investment at least recovered investment costs, even if it did not make a profit. Only 5 percent of respondents indicated that their investment was not successful. The balance was not yet ready to assess their investment. 
Figure 30. Main Investments of Urban MSMEs

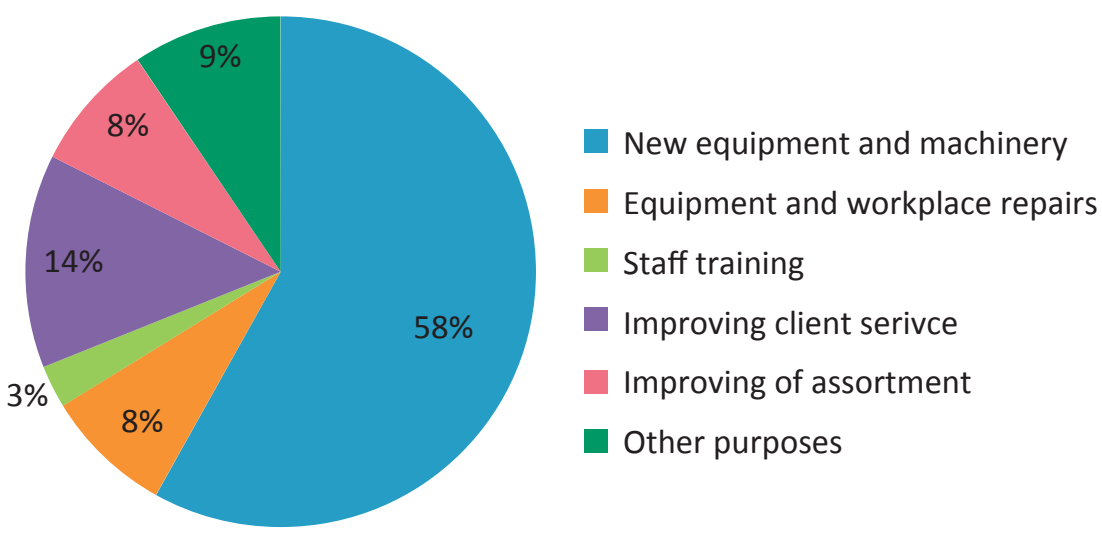

Source: Survey Data

Entrepreneurs report investing in business development based on advice from close contacts, family and business partners (35 percent); the experience of more successful competitors (25 percent); and their own motivation to increase profits (19 percent). Investments were made based on past experience ( 45 percent), the entrepreneur's opinion (31 percent) or information based on competitors' experience (12 percent).

Most investments in urban businesses are made to improve equipment and machinery (see Figure 30). In these cases, equipment was purchased directly on the local market (71 percent) or ordered from a specialised supplier on domestic market (14 percent).

The most significant reasons entrepreneurs gave for not investing in business development include insufficient financial resources (40 percent) and doubts about sufficient profitability (29 percent). They also mention lack of knowledge ( 8 percent) and capital (4 percent). Entrepreneurs also identified the following external and institutional factors which hamper investments:

- It is difficult to expand due to the lack of market space to conduct business (36 percent);

- Business expansion will lead to increased taxes (34 percent); and

- Business growth may lead to increased attention from state bodies (14 percent).

Most respondents agree that investments in technologies and marketing are necessary (71 and 77 percent respectively). However, if entrepreneurs had sufficient finances, their preferred investments would be in new equipment and machinery ( 29 percent), ways to increase turnover (22 percent) and expanding to new markets (14 percent).

To further explore the variables impacting investment decisions by urban entrepreneurs, we created and analysed a simple multinomial logit model for analysis of investment decisions based on categories of collected data.

Two questions to entrepreneurs were selected as dependent variables:

- "Do you invest in your business?" (Model 1), and

- "Was your investment paid off?" (Model 2).

Each statement was represented by the set of ordered responses: 
- $\quad$ Model 1: Yes (1) and No (0),

- Model 2 (an original set of answers was readjusted for the purposes of our analysis):

- 0 - No, investment were lost

- 1 - Investment was basically recovered, without a large profit.

- 2 - Yes, the investment yielded a profit.

The following explanatory variables were selected:

- Presence of credit (1 - no credit for business, or 2 - credit secured for business purposes),

- Period of the current business existence (0.5 - less than 1 year , 2 - over 1 to 3 years , 4 over 3 to 5 years , 7.5 - over 5 to 10 years , 11 - more than 10 years),

- Presence of savings ( 0 - no savings and 1 - savings).

The model specification is described as follows:

$\operatorname{Pr}\left(y_{i}=j\right)=\frac{\exp \left(\beta_{o j}+\beta_{1 j} x_{1 j}+\beta_{2 j} x_{2 j}+\beta_{3 j} x_{3 j}\right)}{\sum_{\mathrm{k}=1}^{3} \exp \left(\beta_{o k}+\beta_{1 k} x_{1 k}+\beta_{2 k} x_{2 k}+\beta_{3 k} x_{3 k}\right)}=P_{i j}$

In which:

- $\mathrm{j}=1,2,3,4$ - categories which y can take,

- $\mathrm{k}=$ number of explanatory variables, and

- $\mathrm{x}_{1}$ - presence of credit

- $\mathrm{x}_{2}$ - working in current business

- $\mathrm{x}_{3}$ - availability of savings

The results are presented in Table 5. In the first model, variables that affect investment decisions were identified. In the second, variables impacting the success of investments were assessed. A different picture emerged with regard to the factors that impact investing by entrepreneurs and those that impact the success of investments.

Two variables were negatively related to the decision to invest in business development: availability of credit and time spent working in current business. Those who operate businesses on credit are risk takers, and investing in business is also a risky exercise. Entrepreneurs seem to simply avoid having double level of business risk.

\section{Table 5. Multinomial Logit Model Estimates of Investment \\ Determinants of Urban Entrepreneurs in Tajikistan}

\begin{tabular}{|c|c|c|c|c|c|c|c|}
\hline \multirow{2}{*}{$\begin{array}{l}\text { Dependent Variable } \\
\text { Number of Observations }\end{array}$} & \multirow[t]{2}{*}{ Coefficient } & \multicolumn{3}{|c|}{$\begin{array}{l}\text { Model 1: } \\
\text { Investment in Business }\end{array}$} & \multicolumn{3}{|c|}{$\begin{array}{c}\text { Model 2: } \\
\text { Successful Investments }\end{array}$} \\
\hline & & 225 & 75 & & & & \\
\hline 1 & 2 & Coef. & $\begin{array}{l}\text { Std. } \\
\text { Error }\end{array}$ & Prob. & Coef. & $\begin{array}{l}\text { Std. } \\
\text { Error }\end{array}$ & Prob. \\
\hline Credit & & -0.32 & 0.18 & 0.07 & -0.57 & 0.29 & 0.05 \\
\hline Period of the current business existence & & -0.04 & 0.02 & 0.07 & 0.04 & 0.04 & 0.28 \\
\hline Savings & & 0.77 & 0.18 & 0.00 & 0.55 & 0.29 & 0.05 \\
\hline
\end{tabular}

Source: Estimations Results from Survey Data

Note: Cells with orange outline indicate a variable affecting the high probability of investing and success to invest, while blue outline indicate variables affecting low probability of the explanatory variable. 
A negative influence on the decision to invest was also related to the length of time spent in the business. The longer an entrepreneur is in a current business, the less likely they are to invest in business development. The evidence suggests that investments are typically made for the initial development of the business and decrease over time after reaching certain levels of turnover and profitability. It should be noted that most respondents are operating as individuals rather than as legal entities.

It also follows from the equation that entrepreneurs who have savings have higher probability to invest in their businesses. One possible explanation of this fact is that availability of savings make the entrepreneurs more comfortable with investment risks as there are resources to cover potential losses associated with investments.

The same set of variables was applied to Model 2, to assess their impact on the success of investments. Accessing credit appeared to be negatively associated with the success of investments, while savings increase the probability of investment success. Thus, entrepreneurs with savings seem to be both motivated and effective investors.

\section{Conclusions and Policy Implications}

This paper builds on research findings that highlight the link between MSMEs and economic growth in Tajikistan. Economic growth is directly linked to the growth of MSMEs in three important sectors of the economy - trade and services, transportation and agriculture. Recent reforms, including support for a simplified tax administration through patent and certificate systems, have contributed to the rapid growth of micro-businesses in Tajikistan in the last decade. Increased awareness of the underestimated role of MSMEs in the production of agricultural exports may contribute to the revitalisation of agricultural growth within the context of limited natural and financial resources. The accession of Tajikistan to the World Trade Organisation in 2013 and the continued liberalisation of trade will also support this process.

To increase understanding of the MSME sector, those working in it and what can help drive its growth, this paper described the results of a survey of randomly selected, cluster-based enterprises in the three key economic sectors in both urban and rural areas across Tajikistan. The dataset provides detailed information on the personal characteristics of entrepreneurs, as well as specific factors influencing the growth of MSMEs, including labour, capital, information and barriers to growth. The findings can help guide policy and programmes that impact the sector and the broader environment in which it functions.

The profile of urban micro-entrepreneurs is different from that of rural entrepreneurs or farmers. Urban entrepreneurs are more likely function as individual agents with high mobility rather than as formal enterprises. A limited number are focused on the creation of jobs. Urban entrepreneurs are motivated to engage in their business due to limited employment options in cities, making entrepreneurship an important form of (self-) employment. Women's participation in MSMEs is high in the urban trade and services sector, and almost non-existent in transportation. 
Rural farmers present another business model; family-based and oriented towards agricultural activity. With household head identified as the entrepreneur in the survey, farmers are older than urban entrepreneurs. In addition to their own livelihood, farmers provide a wide range of employment opportunities in rural areas to both family members and others.

Capital assets are in important indicator of MSME growth for both urban entrepreneurs and rural farmers. The means of production in each sector are different. Key assets for urban entrepreneurs are work space (shops and service areas) and vehicles. Farmers depend on land and livestock. Lack of access to agricultural machinery is a reality of small-scale farming in Tajikistan, making labour a critical asset.

Labour is handled differently in urban and rural businesses. In urban MSMEs, entrepreneurs basically work independently and when they need labour, they involve family and sometimes hire employees. Usually, staff is hired for servicing clients and short-term assignments. Rural labour is mainly hired seasonally for hard manual work, to compensate for lack of machinery. In this way, farmers create a constant market for unemployed young workers. This employment creation role is likely to increase due to economic realities and demographic trends. Immediate and extended family members are usually engaged in urban MSMEs to protect property and control staff. In rural areas, they are similarly assigned roles overseeing business operations and staff. Networking among relatives in agricultural production is an important feature of farming.

Access to credit is an important resource to help MSMEs overcome their lack of financial capital. While interest rates are high in both urban and rural areas, there are some important differences between urban and rural credit markets. Levels of credit in cities and villages vary significantly and microfinance organisations play an important role in providing farmers with credit. For MSMEs in both urban and rural areas, there is a high perceived risk of defaulting on loans.

Information is important to guide successful decision-making in business. In both urban and rural areas, information on markets and prices is important. Entrepreneurs also need to be aware of innovations in business and production. Given this need, there is the potential to develop business and agribusiness media resources for entrepreneurs and public policy makers.

Urban entrepreneurs assessing the external environment identified high taxes among obstacles to MSME growth. Market competition and decreasing demand also impact successful business growth. The majority of entrepreneurs assess the business environment as sustainable and satisfactory. A minority report corruption and unofficial payments. There is a need to further simplify the tax administration and provide education on tax issues to urban businessmen.

Analysis of the determinants of making investments, as well as the success of investment decisions of urban entrepreneurs, provide insight into the necessity of developing education opportunities on business and financial planning for MSME owners. Key topics would be risk management, optimal resource allocation and financial discipline. Enhancing the ability to save is a crucial condition of developing a successful business, and would also engage the banking and financial sector. 


\section{References}

Customs Service under the Government of the Republic of Tajikistan. http://www.customs.tj (date accessed: January 2014).

Roman Mogilevskii and Kamiljon Akramov. "Trade in Agricultural and Food Products in Central Asia." Institute of Public Policy and Administration Working Paper No 27. Bishkek: University of Central Asia, 2014.

Republic of Tajikistan, Law "On State Protection and Support of Entrepreneurship in the Republic of Tajikistan" Edition No. 98, 25 July 2005 and No. 259, 12 May 2007.

Hubert Schmitz. "On the Clustering of Small Firms." Institute of Development Studies Bulletin, 23, 3, 1992: 64-69.

Statistical Agency of the Republic of Tajikistan (SART). National Accounts of the Republic of Tajikistan. Dushanbe: SART, 2010. In Russian/Tajik.

Labour Market Situation of the Republic of Tajikistan. Dushanbe: SART, 2010. In Russian/Tajik. http://www.stat.tj (date accessed: December 2013).

Statistical Yearbook of the Republic of Tajikistan. Dushanbe: SART, 2012. In Russian/Tajik.

Statistical Yearbook of Transportation and Communication in the Republic of Tajikistan 2012.

Dushanbe: SART, 2012. In Russian/Tajik. Agriculture of the Republic of Tajikistan. Dushanbe: SART, 2013. In Russian/Tajik.

Basic Indicators of the Trade and Services Sector of the Republic of Tajikistan. Dushanbe:

SART, 2013. In Russian/Tajik.

The World Bank. http://data.worldbank.org/country/tajikistan (date accessed: December 2013).

"Priorities for Sustainable Growth: A Strategy for Agriculture Sector Development in Tajik-

istan." Technical Report No 68418, 1, 2012: 18-20 (date accessed: December 2013).

"Republic of Tajikistan Country Economic Memorandum: Tajikistan's Quest for Growth: Stimulating Private Investment." Technical Report No. 54677-Tj, 2011 (date accessed: December 2013).

United Nations Statistics Division, Commodity Trade Statistics Database (COMTRADE), http:// comtrade.un.org/db/dqBasicQuery.aspx (date accessed: January 2014). 
Produced by UCA Communications Department

Copy Edited by Sia Nowrojee

Printed by VRS, Bishkek, Kyrgyz Republic 

www.ucentralasia.org 